\title{
A comparative analysis of the intrauterine transcriptome in fertile and subfertile mares using cytobrush sampling
}

\author{
Katharina S. Weber ${ }^{1}$, Karen Wagener ${ }^{1,2}$, Miguel Blanco ${ }^{3}$, Stefan Bauersachs ${ }^{4^{*}+}$ (D) and Heinrich Bollwein ${ }^{1+}$
}

\begin{abstract}
Background: Subfertility is a major problem in modern horse breeding. Especially, mares without clinical signs of reproductive diseases, without known uterine pathogens and no evidence of inflammation but not becoming pregnant after several breeding attempts are challenging for veterinarians. To obtain new insights into the cause of these fertility problems and aiming at improving diagnosis of subfertile mares, a comparative analysis of the intrauterine transcriptome in subfertile and fertile mares was performed. Uterine cytobrush samples were collected during estrus from 57 mares without clinical signs of uterine diseases. RNA was extracted from the cytobrush samples and samples from 11 selected subfertile and 11 fertile mares were used for Illumina RNA-sequencing.

Results: The cytobrush sampling was a suitable technique to isolate enough RNA of high quality for transcriptome analysis. Comparing subfertile and fertile mares, 114 differentially expressed genes (FDR $=10 \%$ ) were identified. Metascape enrichment analysis revealed that genes with lower mRNA levels in subfertile mares were related to 'extracellular matrix (ECM)', 'ECM-receptor interaction', 'focal adhesion', 'immune response' and 'cytosolic calcium ion concentration', while DEGs with higher levels in subfertile mares were enriched for 'monocarboxyl acid transmembrane transport activity' and 'protein targeting'.
\end{abstract}

Conclusion: Our study revealed significant differences in the uterine transcriptome between fertile and subfertile mares and provides leads for potential uterine molecular biomarkers of subfertility in the mare.

Keywords: Mare, Subfertility, Uterine transcriptome, Cytobrush, RNA-seq, Biomarker

\section{Background}

Subfertility represents a substantial problem for the horse breeding industry [1] as it leads to high economic losses for the owners. Subfertile mares do either not conceive or require more examinations, inseminations and treatments to get pregnant than their fertile counterparts. Many factors such as age, reproductive status, gynecological health of the mare, sperm quality, sperm preservation and breeding management have an effect

\footnotetext{
*Correspondence: stefan.bauersachs@uzh.ch

${ }^{\dagger}$ Stefan Bauersachs and Heinrich Bollwein contributed equally to this work. ${ }^{4}$ Institute of Veterinary Anatomy, Vetsuisse Faculty Zurich, University of Zurich, Lindau (ZH), Switzerland

Full list of author information is available at the end of the article
}

on fertility [2-4]. Clinical endometritis is one of the most common causes for fertility problems in mares [1] and was ranked in the top three medical problems in equine adult patients [5]. Endometritis can be divided into acute infectious, chronic infectious or non-infectious endometritis. The most common types of endometritis in mares are bacterially infectious endometritis and persistent breeding induced endometritis (PBIE) [6, 7]. Mares susceptible to PBIE show prolonged persistent post breeding uterine inflammation, interfering with the arrival of the embryo in the uterus 5-6 days after breeding [8]. Mares with endometritis have a lower conception rate and a higher risk for early embryonic death and mid-gestational abortion. Clinical signs of endometritis include intrauterine

(c) The Author(s). 2021 Open Access This article is licensed under a Creative Commons Attribution 4.0 International License, which permits use, sharing, adaptation, distribution and reproduction in any medium or format, as long as you give appropriate credit to the original author(s) and the source, provide a link to the Creative Commons licence, and indicate if changes were made. The images or other third party material in this article are included in the article's Creative Commons licence, unless indicated otherwise in a credit line to the material. If material is not included in the article's Creative Commons licence and your intended use is not permitted by statutory regulation or exceeds the permitted use, you will need to obtain permission directly from the copyright holder. To view a copy of this licence, visit http://creativecommons.org/licenses/by/4.0/. The Creative Commons Public Domain Dedication waiver (http://creativecommons.org/publicdomain/zero/1.0/) applies to the data made available in this article, unless otherwise stated in a credit line to the data. 
fluid, excessive pattern of endometrial edema, vaginitis, vaginal discharge, abnormal estrous cycles and cervicitis. Often endometritis can be diagnosed by detecting clinical signs, uterine inflammation in cytological examination or pathogens in uterine microbial culture [9]. However, there are also mares which don't get pregnant after several breeding attempts with sperm of fertile stallions without showing any pathological signs using these diagnostic methods. Le Blanc and Causey [9] described these disturbances in fertility as hidden cases of endometritis or subclinical endometritis.

Although in many studies the histological examination of uterine biopsy samples was considered as the gold standard for diagnosis endometritis [10-13] and for predicting fertility by using the Kenney and Doig score [14], in practice, currently mostly double-guarded uterine swabs for microbial culture and cytobrushes for cytology are used, as these methods are less invasive than the biopsy and less time consuming than histological examination. The sensitivity of microbial culture and cytology is low and these diagnostic methods have a high incidence of false negative results $[6,10,13,15]$. Many bacteria are difficult to cultivate in vitro and are therefore not detectable by classical bacteriology [16-18]. Moreover, some bacteria, e.g. gram negative bacteria like Escherichia coli don't induce a cellular immunological reaction with a high amount of neutrophils detected by the cytological examination in contrast to other bacteria, such as Streptococci $[1,19]$. Therefore, for mares without clinical signs of uterine diseases, without known pathogens in culture, no evidence of inflammation in cytology but not becoming pregnant after several breeding attempts more accurate diagnostic methods are needed to predict fertility.

It seems likely that underlying mechanisms for subfertility can be found at the molecular level. For instance mares susceptible to persistent endometritis show differences in innate immune response to insemination [8, 20-22] and induced infectious endometritis [23] compared to resistant mares at mRNA expression level. The mRNA expression of pro- inflammatory cytokines (IL6, IL1RN, IL1B, CXCL8), anti-inflammatory cytokines (IL10), tumor necrosis factor (TNF), C-C motif chemokine ligand 2 (CCL2), antimicrobial peptides, secreted phospholipase A2 (PLA2G2A), lipocalin 2 ( $L C N 2)$ and lactotransferrin $(L T F)$ differ between susceptible and resistant mares [8, 20-23]. Recently, it has been shown that mares susceptible for PBIE show a different expression pattern of genes associated with innate immunity even before breeding and that antimicrobial peptides equine b-defensin 1 (DEFB1), lysozyme ( $L Y Z)$ and secretory leukoprotease inhibitor $(S L P I)$ can be used as diagnostic marker for susceptibility [22].

Gene expression profiling of the healthy, receptive equine endometrium has shown that the transcriptome differed among estrous cycle stages [24, 25]. Genes upregulated during estrus were associated with extracellular matrix related categories and immune regulated functions [24, 25]. These physiological changes in uterine gene expression could play an important role in successful reproduction. For instance, the uterine immune system may prepare the uterus for potential foreign material ascending through the open cervix during estrus by upregulation of genes related to immune response [24, 25].

In recent years, gene expression analysis has been applied in several studies to identify genes and their networks associated with receptivity of the human endometrium at the time of implantation by comparing women with recurrent miscarriage $[26,27]$ or recurrent implantation failure $[26,28-30]$ and fertile women. Furthermore, in cows, different studies were performed to identify endometrial gene expressions related to fertility [31-35]. However, to our knowledge, no study investigated yet the relationship between the equine uterine transcriptome and fertility in mares using cytobrush samples collected during estrus.

In most of the equine and human studies uterine biopsy samples were taken for transcriptome and mRNA analysis, while in cattle cytobrush samples were often used for mRNA analysis. In different bovine studies, it was shown that cytobrush sampling provides a much less invasive method to isolate RNA of sufficient quantity and quality for gene expression analysis [31, 36] compared to the biopsy of the endometrium.

With the aim to improve the diagnosis of subfertile mares without clinical signs of uterine diseases and to characterize RNA markers to predict fertility, our objective was to perform a comparative analysis of the intrauterine transcriptome at estrus of fertile and subfertile mares without clinical signs of uterine diseases. A second objective was to investigate the suitability of samples collected by cytobrush from the equine uterus for transcriptome analysis.

\section{Results \\ Cytology and bacteriology}

The cytological examination did not reveal an intrauterine inflammation at the time of sampling in all mares. Bacteria were detected in 33 of 57 mares (57.9\%) in microbial culture. Facultative pathogens were obtained in 12 of 57 mares (21.1\%). These 12 samples with facultative pathogens were excluded from further analysis. From each group of the fertile mares (FB-P) and subfertile mares (RB-N) 11 mares without facultative pathogens were selected for RNA sequencing.

\section{Isolation of RNA from cytobrush samples and Illumina RNA-sequencing}

The cytobrush sampling was a suitable technique to isolate enough RNA of high quality for transcriptome 
analysis. The concentration of the total RNA was between 40 and $669 \mathrm{ng} / \mu \mathrm{l}$, while the A260/A280 ratio was between 1.95 and 2.09. The obtained RNA integrity numbers (RIN) ranged from 8.9 to 10 in all 57 samples.

The RNA sequencing results revealed after filtering of the fastq files library sizes between 10.9 and 30.9 million reads per sample with an average of 18.4 million reads. After filtering genes with low read counts, in total 15, 318 different genes were detectable and used for differential gene expression analysis.

\section{Identification of differentially expressed genes}

The intrauterine transcriptome differed between subfertile and fertile mares without clinical signs of uterine diseases. Using Edge $\mathrm{R}$ analysis, 114 genes were found as differentially expressed between subfertile and fertile mares (FDR < 0.1; Fig. 1) (Additional file 1). Ninety-eight genes were significantly downregulated and 16 genes upregulated in subfertile mares compared to fertile mares. The expression of neuromedin $\mathrm{U}(N M U)$, synaptogamin 12 (SYT12), uncharacterized LOC111767890, UL16 binding protein 1 (LOC100063831) were decreased to the greatest extent, while the expression of solute carrier family 10 member 2 (SLC10A2), 40 S ribosomal protein S2-like (LOC100147232) and 60S ribosomal protein L26-like (LOC10052427) were increased to the greatest extent in subfertile mares compared to fertile mares.

Hierarchical cluster analysis of the DEGs revealed a separation of DEGs upregulated (cluster 1) or downregulated (clusters 2, 3,4) in samples derived from subfertile mares (Fig. 1). The downregulated genes were separated in three clusters. Cluster 2 showed DEGs with increased expression in only 5 of the fertile mares. Differences in cluster 3 and 4 were more consistent above all samples. A few samples of the subfertile and fertile group, respectively, showed expression patterns in part more similar to the respective other group. The DEGs of cluster 1 and the DEGs of clusters 3 and 4 are listed in Tables 1 and 2, respectively.

\section{Overrepresented functional categories}

The DEGs were analyzed for overrepresented functional categories and pathways in fertile or subfertile mares using the Metascape enrichment analysis tool (Table 3, Fig. 2, Additional file 2). The analyses were performed separately for genes upregulated or downregulated in subfertile mares compared to fertile mares, uploading the corresponding human NCBI Entrez gene IDs. Eighty-five genes of the downregulated genes and 12 of the upregulated genes could be assigned to a corresponding human gene symbol.

For genes with lower expression in subfertile compared to fertile mares, functional categories such as 'extracellular matrix (ECM)', 'lymphocyte mediated immunity', 'immune response', 'positive regulation of cytosolic calcium ion concentration' and 'peptidyl-tyrosine phosphorylation' were found as overrepresented. The most significantly enriched KEGG pathways were 'ECM-receptor interaction' (Fig. 3), 'focal adhesion' and 'PI3K-Akt signaling pathway'. DEGs upregulated in subfertile mares were enriched for 'monocarboxyl acid transmembrane transporter activity' and 'protein targeting'.

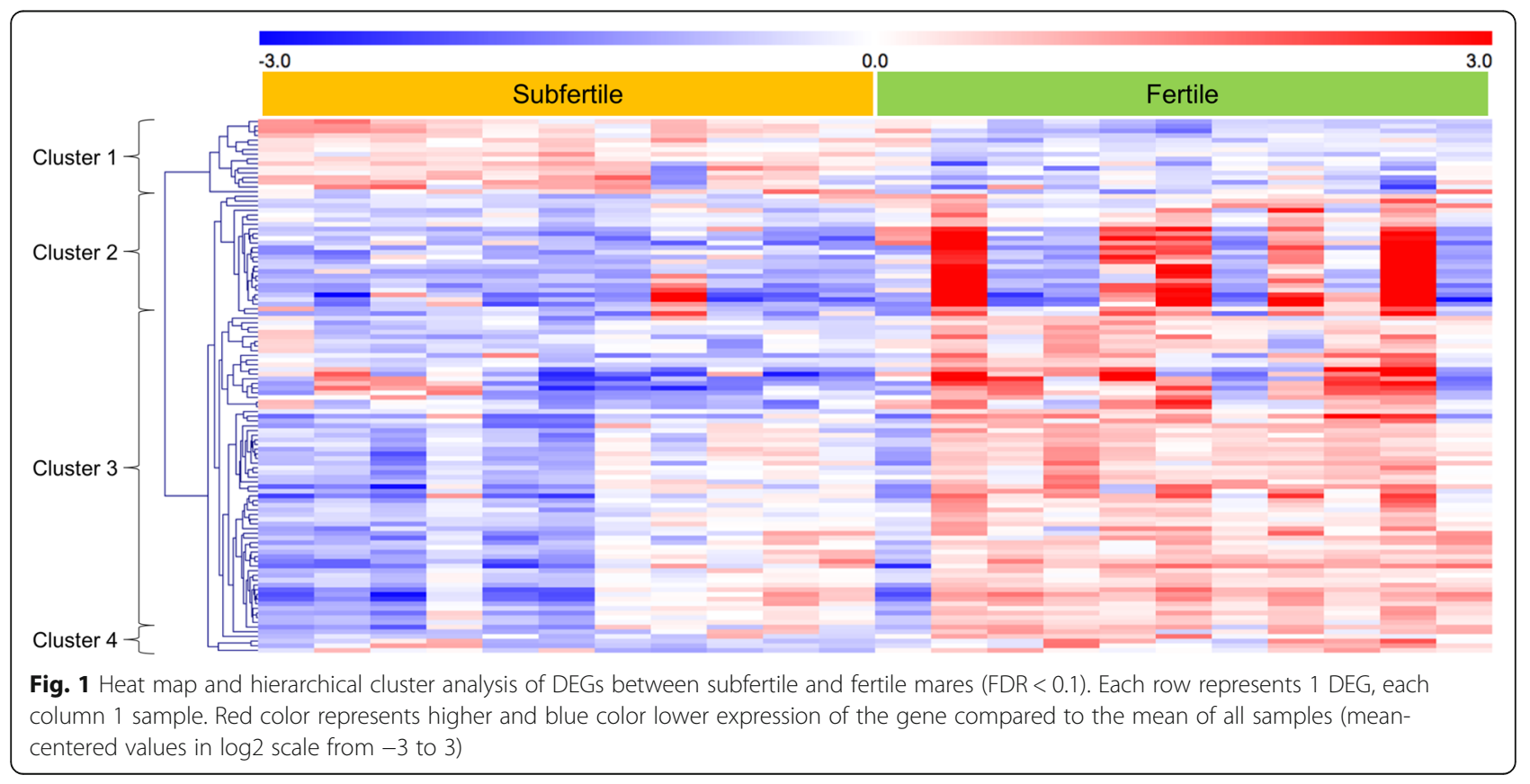


Table 1 DEGs of Cluster1: DEGs upregulated in subfertile mares compared to fertile mares

\begin{tabular}{|c|c|c|c|c|c|c|}
\hline Gene symbol & Entrez Gene ID & Gene description & Human gene symbol & $\log 2$ FC SUB/FER & $P$-value & FDR \\
\hline SLC1OA2 & 100051264 & solute carrier family 10 member 2 & SLC10A2 & 1.82 & 0.0002 & 0.0591 \\
\hline LOC100147232 & 100147232 & $40 S$ ribosomal protein S2 like & & 1.80 & 0.0000 & 0.0012 \\
\hline LOC100052427 & 100052427 & 605 ribosomal protein L26-like & & 1.64 & 0.0000 & 0.0200 \\
\hline LOC100051778 & 100051778 & 605 ribosomal protein L21 & RPL21 & 1.63 & 0.0000 & 0.0035 \\
\hline LOC100065786 & 100065786 & $40 S$ ribosomal protein S17 & RPS17 & 1.46 & 0.0000 & 0.0014 \\
\hline LOC100067178 & 100067178 & Mesothelin & MSLN & 1.13 & 0.0005 & 0.0861 \\
\hline SLC16A9 & 100062703 & solute carrier family 16 member 9 & SLC16A9 & 0.98 & 0.0001 & 0.0417 \\
\hline ELOVL2 & 100063624 & ELOVL fatty acid elongase 2 & ELOVL2 & 0.96 & 0.0001 & 0.0474 \\
\hline LOC111767704 & 111767704 & uncharacterized LOC111767704 & & 0.91 & 0.0000 & 0.0179 \\
\hline CRYL1 & 100054141 & crystallin lambda 1 & CRYLI & 0.89 & 0.0001 & 0.0338 \\
\hline CTSE & 100055161 & cathepsin E & CTSE & 0.82 & 0.0002 & 0.0591 \\
\hline LOC100072143 & $100,072,143$ & centrin-4 & & 0.80 & 0.0001 & 0.0318 \\
\hline SLC16A5 & 100060017 & solute carrier family 16 member 5 & SLC16A5 & 0.57 & 0.0005 & 0.0861 \\
\hline TOMM7 & 100630688 & translocase of outer mitochondrial membrane 7 & TOMM7 & 0.52 & 0.0002 & 0.0591 \\
\hline MYCBP & 100068904 & MYC binding protein & MYCBP & 0.47 & 0.0002 & 0.0564 \\
\hline SDHAF4 & 100629833 & succinate dehydrogenase complex assembly factor 4 & SDHAF4 & 0.45 & 0.0004 & 0.0763 \\
\hline
\end{tabular}

\section{Validation of RNA-seq results by quantitative real-time RT-PCR}

Expression differences found by RNA-sequencing were confirmed by qRT-PCR for 10 selected DEGs (Table 4). The qRT-PCR and RNA-seq relative expression values correlated well for the 22 analyzed samples (Fig. 4).

\section{Discussion}

To our knowledge, this is the first study investigating the relationship between uterine transcriptome and fertility in mares using cytobrush samples collected during estrus. Our study showed that sufficient amounts of high-quality RNA can be isolated from uterine cytobrush samples collected from mares. All obtained RNA samples showed RINs between 8.9 and 10 and revealed a minimum of $560 \mathrm{ng}$ total RNA. In contrast to biopsy samples, the cytobrush technique does not provide information about gene expression of the whole endometrium as the cytobrush tends to collect only superficial parts of the endometrium and uterine fluid. To our knowledge, there is no study that examined, which material is exactly collected by the cytobrush. However, cytological examinations of uterine cytobrush samples in mares show primarily uterine epithelial cells, white blood cells and red blood cells [17]. In our study, the cytological examination confirmed mainly uterine epithelial cells, erythrocytes and some isolated white blood cells. Comparing biopsy and cytobrush samples in cattle, stromal and endothelial cells were enriched in biopsy samples, while endometrial epithelial cells and immune cell markers were enriched in cytobrush samples [38]. A previous study in mares at the time of recognition of pregnancy showed that the strongest gene expression differences between pregnant and cyclic state are localized in the luminal epithelium [39]. Therefore, we also expected the highest differences between fertile and subfertile mares in the endometrial epithelium, which is collected with the cytobrush samples. Cytobrush samples therefore represent a less invasive sampling alternative to the biopsy sample for transcriptome analysis. However, the different sample compositions of cytobrush and biopsy samples still need to be investigated in more detail and therefore existing fertility and endometritis markers from biopsy samples cannot always be transferred to cytobrush samples.

The comparative transcriptome analysis of cytobrush samples collected during estrus revealed significant differences in the intrauterine gene expression between subfertile mares without clinical signs of reproductive diseases and normal fertile mares. Estrus was selected to allow easy sampling through the open cervix and to develop markers for the evaluation of fertility in mares before insemination based on routine cytobrush sampling. Early diagnosis of subfertile mares gives the possibility to improve the fertility of the mare with an optimized breeding management. In the present study, the mares were divided into fertile and subfertile mares according to pregnancy diagnosis after artificial inseminations during one breeding season. Mares becoming pregnant after only one artificial insemination (AI) were assumed fertile, mares that failed to conceive after at least three AIs were classified as subfertile. However, we are aware that probably not all mares classified as fertile are really fertile. Also, subfertile mares could become pregnant just 
Table 2 DEGs of Clusters 3 and 4: DEGs downregulated in subfertile mares compared to fertile mares

\begin{tabular}{|c|c|c|c|c|c|c|}
\hline Gene symbol & Entrez Gene ID & Gene description & $\begin{array}{l}\text { Human gene } \\
\text { symbol }\end{array}$ & $\begin{array}{l}\log 2 \text { FC } \\
\text { SUB/FER }\end{array}$ & $P$-value & FDR \\
\hline ACAP1 & 100072970 & ArfGAP with coiled-coil, ankyrin repeat and PH domains 1 & ACAP1 & -1.01 & 0.0000 & 0.0291 \\
\hline ACKR3 & 100057501 & atypical chemokine receptor 3 & ACKR3 & -1.60 & 0.0001 & 0.0474 \\
\hline ADAMTS7 & 100059959 & ADAM metallopeptidase with thrombospondin type 1 motif 7 & ADAMTS7 & -1.39 & 0.0001 & 0.0318 \\
\hline AKRIE2 & 100070632 & aldo-keto reductase family 1 member E2 & AKRIE2 & -1.93 & 0.0000 & 0.0179 \\
\hline ANKRD10 & 100066458 & ankyrin repeat domain 10 & ANKRD10 & -0.66 & 0.0007 & 0.0998 \\
\hline ANO8 & 100146761 & anoctamin 8 & ANO8 & -1.24 & 0.0004 & 0.0763 \\
\hline APBA3 & 100146445 & amyloid beta precursor protein binding family A member 3 & APBA3 & -0.62 & 0.0003 & 0.0708 \\
\hline CIQA & 100058097 & complement C1q A chain & CIQA & -0.66 & 0.0006 & 0.0861 \\
\hline$C 1 Q B$ & 100071667 & complement C1q B chain & $C 1 Q B$ & -0.74 & 0.0002 & 0.0562 \\
\hline CEP131 & 100056159 & centrosomal protein 131 & CEP131 & -0.85 & 0.0002 & 0.0529 \\
\hline $\mathrm{CIAO3}$ & 100065271 & cytosolic iron-sulfur assembly component 3 & $\mathrm{ClAO} 3$ & -0.57 & 0.0007 & 0.0998 \\
\hline CLK1 & 100067832 & CDC like kinase 1 & CLK1 & -0.94 & 0.0004 & 0.0796 \\
\hline CLK2 & 100063546 & CDC like kinase 2 & CLK2 & -0.69 & 0.0006 & 0.0861 \\
\hline COL16A1 & 100056083 & collagen type XVI alpha 1 chain & COL16A1 & -1.72 & 0.0005 & 0.0847 \\
\hline COL4A1 & 100066148 & collagen type IV alpha 1 chain & COL4A1 & -1.16 & 0.0003 & 0.0658 \\
\hline COLAA2 & 100066264 & collagen type IV alpha 2 chain & COL4A2 & -1.17 & 0.0001 & 0.0354 \\
\hline COL6A1 & 100050035 & collagen type $\mathrm{VI}$ alpha 1 chain & COL6A1 & -1.84 & 0.0006 & 0.0897 \\
\hline CYTH4 & 100069735 & cytohesin 4 & CYTH4 & -0.79 & 0.0004 & 0.0798 \\
\hline DENNDIC & 100065730 & DENN domain containing $1 C$ & DENNDIC & -0.91 & 0.0006 & 0.0861 \\
\hline DLG4 & 100061544 & discs large MAGUK scaffold protein 4 & DLG4 & -0.98 & 0.0003 & 0.0643 \\
\hline DNASE1L3 & 100057863 & deoxyribonuclease 1 like 3 & DNASE1L3 & -1.66 & 0.0001 & 0.0474 \\
\hline EHBPIL1 & 100057282 & EH domain binding protein 1 like 1 & EHBP1L1 & -0.93 & 0.0001 & 0.0417 \\
\hline ENTPD6 & 100057043 & ectonucleoside triphosphate diphosphohydrolase 6 & ENTPD6 & -0.70 & 0.0003 & 0.0620 \\
\hline FER1L5 & 100062182 & fer-1 like family member 5 & FERTL5 & -1.77 & 0.0002 & 0.0591 \\
\hline FN1 & 100034189 & fibronectin 1 & FN1 & -2.21 & 0.0001 & 0.0472 \\
\hline GRAMDIB & 100063638 & GRAM domain containing 1B & GRAMD1B & -0.61 & 0.0004 & 0.0763 \\
\hline IRF8 & 100056218 & interferon regulatory factor 8 & IRF8 & -0.79 & 0.0005 & 0.0861 \\
\hline JAK3 & 100147451 & Janus kinase 3 & JAK3 & -0.66 & 0.0003 & 0.0673 \\
\hline KIF7 & 100069672 & kinesin family member 7 & KIF7 & -0.82 & 0.0006 & 0.0867 \\
\hline LAT & 100064430 & linker for activation of $\mathrm{T}$ cells & LAT & -0.93 & 0.0001 & 0.0417 \\
\hline LLGL1 & 100051856 & LLGL1, scribble cell polarity complex component & LLGL1 & -0.50 & 0.0006 & 0.0861 \\
\hline LOC100054029 & 100054029 & leukocyte immunoglobulin-like receptor subfamily A member 5 & & -1.26 & 0.0006 & 0.0883 \\
\hline LOC100054448 & 100054448 & saoe class I histocompatibility antigen, A alpha chain & $H L A-A$ & -1.26 & 0.0000 & 0.0024 \\
\hline LOC100055483 & 100055483 & Ig mu chain $\mathrm{C}$ region membrane-bound form-like & IGHM & -1.82 & 0.0003 & 0.0609 \\
\hline LOC100063097 & 100063097 & mitotic-spindle organizing protein 2B-like & $M Z T 2 B$ & -1.70 & 0.0001 & 0.0423 \\
\hline LOC100073089 & 100073089 & $\begin{array}{l}\text { ectonucleotide pyrophosphatase/phosphodiesterase } \\
\text { family member } 3\end{array}$ & ENPP3 & -1.26 & 0.0000 & 0.0200 \\
\hline LOC100629324 & 100629324 & uncharacterized LOC100629324 & MEG3 & -2.85 & 0.0001 & 0.0417 \\
\hline LOC102149846 & 102149846 & immunoglobulin heavy constant gamma 1-like & IGHG1 & -2.14 & 0.0005 & 0.0861 \\
\hline LOC102150085 & 102150085 & immunoglobulin heavy constant gamma 1-like & $\mid G H G 1$ & -2.67 & 0.0000 & 0.0240 \\
\hline LOC102150790 & 102150790 & uncharacterized LOC102150790 & & -1.44 & 0.0000 & 0.0179 \\
\hline LOC106781059 & 106781059 & uncharacterized LOC106781059 & & -1.46 & 0.0001 & 0.0327 \\
\hline LOC106781303 & 106781303 & immunoglobulin heavy constant alpha 2-like & $|G H A|$ & -1.98 & 0.0005 & 0.0861 \\
\hline LOC106781940 & 106781940 & uncharacterized LOC106781940 & & -1.45 & 0.0004 & 0.0762 \\
\hline
\end{tabular}


Table 2 DEGs of Clusters 3 and 4: DEGs downregulated in subfertile mares compared to fertile mares (Continued)

\begin{tabular}{|c|c|c|c|c|c|c|}
\hline Gene symbol & Entrez Gene ID & Gene description & $\begin{array}{l}\text { Human gene } \\
\text { symbol }\end{array}$ & $\begin{array}{l}\log 2 \text { FC } \\
\text { SUB/FER }\end{array}$ & $P$-value & FDR \\
\hline LOC106783330 & 106783330 & uncharacterized LOC106783330 & & -1.67 & 0.0001 & 0.0417 \\
\hline LOC111767520 & 111767520 & uncharacterized LOC111767520 & & -1.60 & 0.0003 & 0.0669 \\
\hline LOC111768661 & 111768661 & translation initiation factor IF-2-like & & -1.19 & 0.0006 & 0.0897 \\
\hline LOC111768809 & 111768809 & uncharacterized LOC111768809 & & -2.47 & 0.0000 & 0.0113 \\
\hline LOC111771758 & 111771758 & GTPase IMAP family member 5-like & & -0.92 & 0.0001 & 0.0474 \\
\hline LOC111774331 & 111774331 & uncharacterized LOC111774331 & & -1.17 & 0.0003 & 0.0620 \\
\hline MCF2L & 100067048 & MCF.2 cell line derived transforming sequence like & MCF2L & -0.74 & 0.0001 & 0.0405 \\
\hline MICAL1 & 100066627 & $\begin{array}{l}\text { microtubule associated monooxygenase, calponin and LIM } \\
\text { domain containing } 1\end{array}$ & MICAL1 & -0.90 & 0.0000 & 0.0263 \\
\hline MMP25 & 100068942 & matrix metallopeptidase 25 & MMP25 & -1.10 & 0.0003 & 0.0619 \\
\hline NAAA & 100057831 & N-acylethanolamine acid amidase & NAAA & -1.04 & 0.0003 & 0.0642 \\
\hline NUP210L & 100056659 & nucleoporin 210 like & NUP210L & -1.11 & 0.0002 & 0.0553 \\
\hline PDEIOA & 100050311 & phosphodiesterase 10A & PDE10A & -2.44 & 0.0000 & 0.0195 \\
\hline PLCB2 & 100057315 & phospholipase $\mathrm{C}$ beta 2 & PLCB2 & -0.93 & 0.0005 & 0.0861 \\
\hline PLXNA3 & 100058349 & plexin A3 & PLXNA3 & -1.31 & 0.0005 & 0.0861 \\
\hline PREX1 & 100071328 & $\begin{array}{l}\text { phosphatidylinositol-3,4,5-trisphosphate dependent Rac } \\
\text { exchange factor } 1\end{array}$ & PREX1 & -0.68 & 0.0006 & 0.0861 \\
\hline RAB44 & 100629655 & RAB44, member RAS oncogene family & RAB44 & -1.29 & 0.0005 & 0.0861 \\
\hline RYR1 & 100034090 & ryanodine receptor 1 & RYR1 & -1.31 & 0.0004 & 0.0737 \\
\hline$S L C 8 B 1$ & 100056481 & solute carrier family 8 member B1 & $S L C 8 B 1$ & -0.66 & 0.0003 & 0.0676 \\
\hline SNRNP70 & 100054907 & small nuclear ribonucleoprotein U1 subunit 70 & SNRNP70 & -0.74 & 0.0002 & 0.0591 \\
\hline THBS2 & 100050044 & thrombospondin 2 & THBS2 & -3.13 & 0.0000 & 0.0294 \\
\hline TIA1 & 100050503 & TIA1 cytotoxic granule associated RNA binding protein & TIA1 & -0.55 & 0.0006 & 0.0861 \\
\hline TNNT2 & 100146343 & troponin T2, cardiac type & TNNT2 & -2.20 & 0.0001 & 0.0417 \\
\hline TNXB & 100059315 & tenascin XB & $T N X B$ & -1.19 & 0.0000 & 0.0240 \\
\hline TOP3B & 100051153 & DNA topoisomerase III beta & TOP3B & -0.92 & 0.0002 & 0.0602 \\
\hline TPCN2 & 102150167 & two pore segment channel 2 & TPCN2 & -0.76 & 0.0002 & 0.0591 \\
\hline VGLL3 & 100069930 & vestigial like family member 3 & VGLL3 & -1.41 & 0.0006 & 0.0883 \\
\hline WDR90 & 100066920 & WD repeat domain 90 & WDR90 & -0.75 & 0.0005 & 0.0861 \\
\hline ZBP1 & 100055754 & Z-DNA binding protein 1 & $Z B P 1$ & -0.96 & 0.0000 & 0.0294 \\
\hline ZNF333 & 100064631 & zinc finger protein 333 & ZNF333 & -0.67 & 0.0007 & 0.0998 \\
\hline
\end{tabular}

by chance with the first $\mathrm{AI}$ and were considered as fertile in our classification. This could be also a reason why the hierarchical cluster analysis of the identified DEGs did not show a complete and clear separation of the two groups of mares into two clusters. Some mares showed intermediate expression patterns or patterns more similar to the other group. Classification after multiple AIs and pregnancy diagnosis, as in the study of Killeen et al. [40] in cattle, would have been better, but was not possible in the stud farm due to financial, logistical and ethical reasons. Moreover, we cannot exclude, if fertility was affected by the stallion, although we included only mares in our study inseminated with chilled semen from fertile stallions. Furthermore, in the subfertile mares, samples were collected after at least two unsuccessful inseminations in previous cycles, whereas in the fertile mares the samples were taken before the first insemination in the breeding season. Therefore, previous inseminations in the subfertile mares could have an influence on the intrauterine transcriptome. In addition, the small number of 11 mares per group probably limited the power of the comparative transcriptome analysis results. Further studies have to validate the DEGs found here in a larger number of samples.

In total, 114 genes were found as differentially expressed between subfertile and fertile mares. Quantitative real-time RT-PCR confirmed the results for 10 selected DEGs. The majority of the DEGs showed uniform 
Table 3 Metascape functional term enrichment analysis of DEGs subfertile vs fertile mares

\begin{tabular}{|c|c|c|}
\hline Most informative categories of Metascape enrichment analysis & $\begin{array}{l}\log _{10} \\
(P \text {-value) }\end{array}$ & Assigned genes \\
\hline \multicolumn{3}{|l|}{ Genes with lower expression in subfertile vs. fertile mares } \\
\hline $\begin{array}{l}\text { Extracellular matrix, ECM-receptor interaction, Focal } \\
\text { adhesion, Collagen trimer, PI3-Akt signaling pathway }\end{array}$ & -7.8 & $\begin{array}{l}\text { COL4A1,COL4A2,COL6A1,FN1,ITGB3,THBS2,TNXB,COL16A1,C1QA,C1QB, } \\
\text { ACHE,MMP25,FGFR1,JAK3,SLC39A8,ADAMTS7,PNPLA2,ANO8,DLG4, TIA1, } \\
\text { PLCB2, PLXNA3,LLGL1,ACKR3,PDE2A,RYR1,ERFE,AKR1C4,CLK2 }\end{array}$ \\
\hline $\begin{array}{l}\text { Lymphocyte mediated immunity, complement } \\
\text { activation, adaptive immune response }\end{array}$ & -4.4 & $\begin{array}{l}\text { C1QA, C1QB,HLAA,IGHA1,IGHG1,IGHM,CLCF1,ULBP3,JAK3,FN1, } \\
\text { DLG4,ENPP3,STAC,ACKR3,LAT,PREX1,IRF8,ITGB3 }\end{array}$ \\
\hline $\begin{array}{l}\text { Positive regulation of cytosolic calcium ion concentration, } \\
\text { muscle contraction }\end{array}$ & -3.8 & $\begin{array}{l}\text { DLG4,PLCB2,RYR1,NMU,ACKR3,SLC8B1,TPCN2,SLC39A8,ERFE,COL6A1, } \\
\text { STAC,ITGB3,PNPLA2,FGFR1,SYT12,ATP8B2,ANO8,TNNT2 }\end{array}$ \\
\hline Glycosaminoglycan binding & -3.8 & COL16A1,FGFR1,FN1,IGHM,THBS2,TNXB,ITGB3,PREX1,IGHA1,SLC8B1 \\
\hline Regulation of immune effector process & -3.7 & C1QA,C1QB,DNASE1L3,HLA-A,IGHG1,JAK3,ENPP3, CLCF1,ULBP3 \\
\hline Peptidyl-tyrosine phosphorylation & -3.5 & DLG4,FGFR1,FN1,ITGB3,JAK3,LAT,CLK1,CLK2,CLCF1,IGHG1,COL16A1,PLCB2 \\
\hline Inorganic anion transport & -3.5 & $\begin{array}{l}\text { DLG4,FGFR1,FN1,ITGB3,JAK3,LAT,CLK1,CLK2,CLCF1,IGHG1,COL16A1, } \\
\text { PLCB2 }\end{array}$ \\
\hline Phosphoric diester hydrolase activity & -3.4 & PDE2A,ENPP3,PLCB2,PDE1OA,ENTPD6 \\
\hline $\begin{array}{l}\text { Receptor internalization, receptor-mediated } \\
\text { endocytosis }\end{array}$ & -3.1 & ACHE,DLG4,ITGB3,ACKR3,IGHA1 \\
\hline Hallmark Myogenesis, calcium ion binding & -3.1 & $\begin{array}{l}\text { ACHE,COL4A2,RYR1,TNNT2,HSPB8,ENTPD6,SYT12,C1QA,DLG4, } \\
\text { DNASE1L3,ENPP3,PLCB2,THBS2,RAB44 }\end{array}$ \\
\hline \multicolumn{3}{|l|}{ Genes with higher expression in subfertile vs. fertile mares } \\
\hline Monocarboxylic acid transmembrane transport activity & -5.6 & SLC10A2, SLC16A5, SLC16A9 \\
\hline Protein targeting & -3.0 & RPL21,RPS17, TOMM7 \\
\hline
\end{tabular}

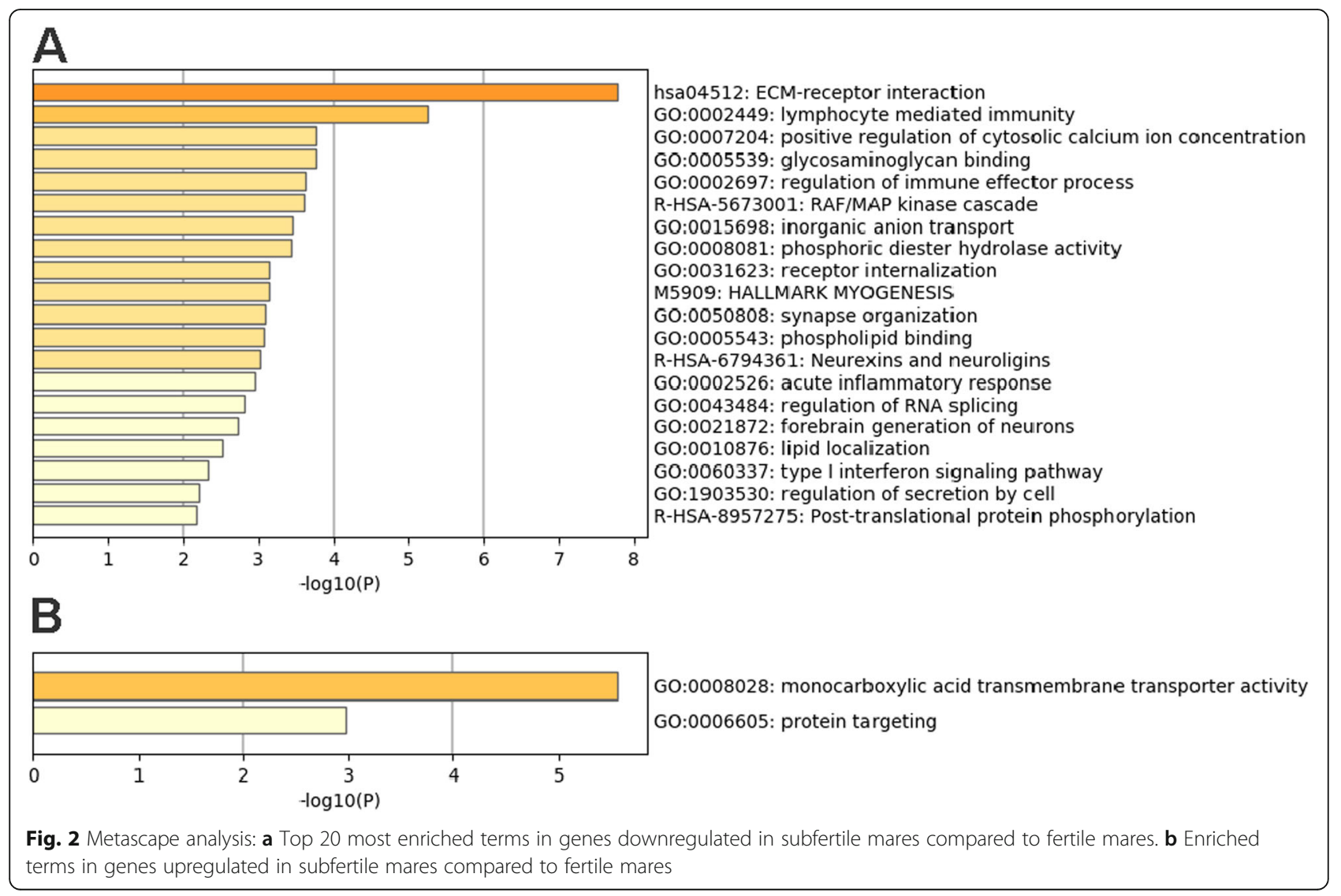




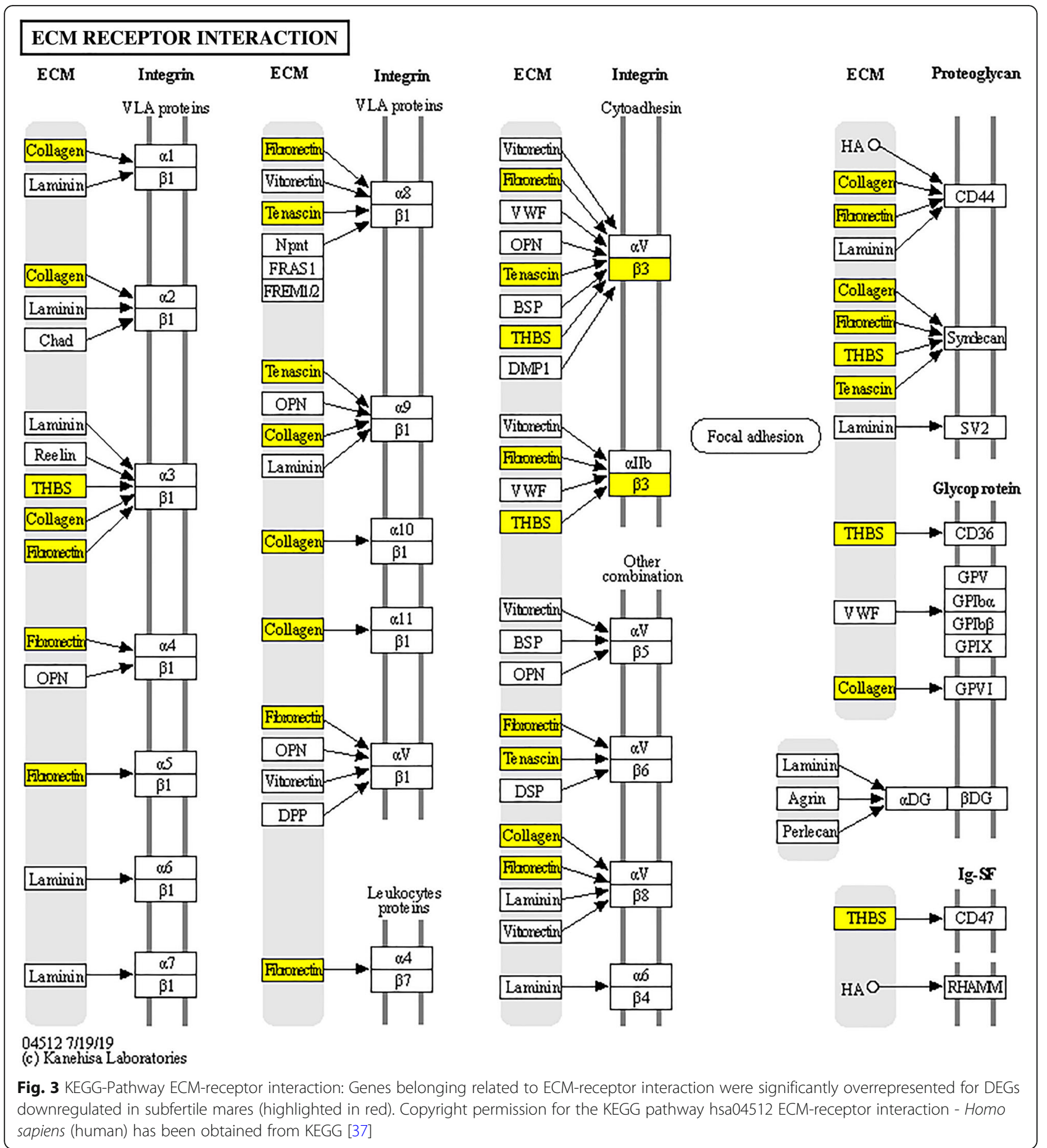

expression in the respective fertility groups suggesting them as good candidates for RNA markers to diagnose subfertile mares without clinical signs of reproductive diseases and to predict fertility. A part of the DEGs (cluster 2 in the hierarchical cluster analysis) showed only increased expression in some of the samples of the fertile group, making these DEGs unsuitable as markers. No similarity could be found in these samples with respect to data records of these mares, which would distinguish them from the other samples. It seems likely that low mRNA levels of the genes of cluster 2 do not cause subfertility as a sole factor but may decrease fertility in conjunction with other disturbances.

According to the functional enrichment analysis, genes related to 'extracellular matrix', 'ECM-receptor interaction', 'focal adhesion', 'immune response', and 'cytosolic 
Table 4 Quantification of selected genes with quantitative realtime RT-PCR and comparison with RNA sequencing results

\begin{tabular}{llllll}
\hline $\begin{array}{l}\text { Gene } \\
\text { symbol }\end{array}$ & q-RT-PCR & & & \multicolumn{2}{c}{ RNA-Sequencing } \\
\cline { 2 - 3 } \cline { 6 - 7 } & Log2 FC & P-value & & Log2 FC & FDR \\
\hline SLC10A2 & 1.7 & 0.0497 & & 1.8 & 0.0368 \\
SLC16A9 & 1.2 & 0.0127 & & 1.0 & 0.0200 \\
ITGB3 & -1.9 & 0.0095 & -1.3 & 0.0113 \\
THBS2 & -2.1 & 0.0269 & -3.2 & 0.0080 \\
FN1 & -1.6 & 0.0156 & -2.5 & 0.0065 \\
COL6A1 & -1.4 & 0.0313 & & -1.9 & 0.0460 \\
ACKR3 & -1.3 & 0.0084 & -1.6 & 0.0242 \\
PDE10A & -1.7 & 0.0130 & & -2.4 & 0.0080 \\
MMP25 & -0.7 & 0.0388 & & -1.1 & 0.0375 \\
ENPP3 & -1.2 & 0.0143 & -2.2 & 0.0200 \\
\hline
\end{tabular}

calcium concentration' may play an important role in fertility, as intrauterine gene expression levels related to these categories were lower in subfertile mares compared to fertile mares. Genes with higher mRNA concentrations in samples derived from subfertile mares were related to 'monocarboxyl acid transmembrane transport activity' and 'protein targeting'. A comparison with human fertility studies is difficult as these studies were often not conducted at estrus like our study. In the following, selected DEGs potentially important for fertility are discussed.

\section{ECM related genes downregulated in subfertile mares}

Genes with lower mRNA levels in samples collected from subfertile mares were most significantly enriched for functional categories associated with 'extracellular matrix (ECM)', 'collagen trimer', 'extracellular matrix organization', 'ECM-receptor interaction', 'focal adhesion', and 'angiogenesis'. In our study the mRNA expression of 4 collagens (COL4A1, COLAA2, COL6A1,
COL16A1), 4 ECM glycoproteins (fibronectin 1- FN1, thrombospondin 2 - THBS2, tenascin XB - TNXB, acetylcholinesterase (Cartwright blood group) - $A C H E$ ), the ECM receptor integrin subunit beta 3 (ITGB3) and two ECM modifiers (ADAMTS5, MMP25) was lower in subfertile mares compared to fertile mares. The genes ITGB3, THBS2, TNXB, COL4A1, COL6A1, COL4A2 and FN1 are involved in 'ECM receptor interaction' and 'focal adhesion' pathway, referring to the interaction of cells with the ECM, whereby integrins or proteoglycans establish the link between ECM and cells.

Previous studies showed that ECM-related uterine gene expression varied during the equine estrous cycle $[24,25]$. Genes related to ECM, focal adhesion and angiogenesis were upregulated during estrus in equine endometrium [24, 25], which suggests an important function of these genes during estrus, that has not been clarified yet. Our study indicates that higher expression levels of genes related to ECM and focal adhesion during estrus might be important for fertility, as subfertile mares showed lower mRNA levels of these genes.

Genes related to ECM and cell adhesion were identified in fertility studies in humans at time of implantation as dysregulated genes in the endometrium of women with unexplained infertility or with recurrent miscarriage $[27,29,41]$. For instance the gene ITGB3, one DEG of cluster 2 , is a marker of endometrial receptivity at the window of implantation in women and mice [42-44]. However, not much is known about the function of ECM related uterine genes and its relation to fertility at estrus, the time point of our sampling, as most human fertility studies are conducted during secretory phase.

Ectonucleotide pyrophosphatase/phosphodiesterase 3 (ENPP3) protein expression was only found in cyclic and not in postmenopause endometria of women indicating a relation with fertility [45]. In the study of Klein et al. [46], uterine ENPP3 mRNA was upregulated in pregnant

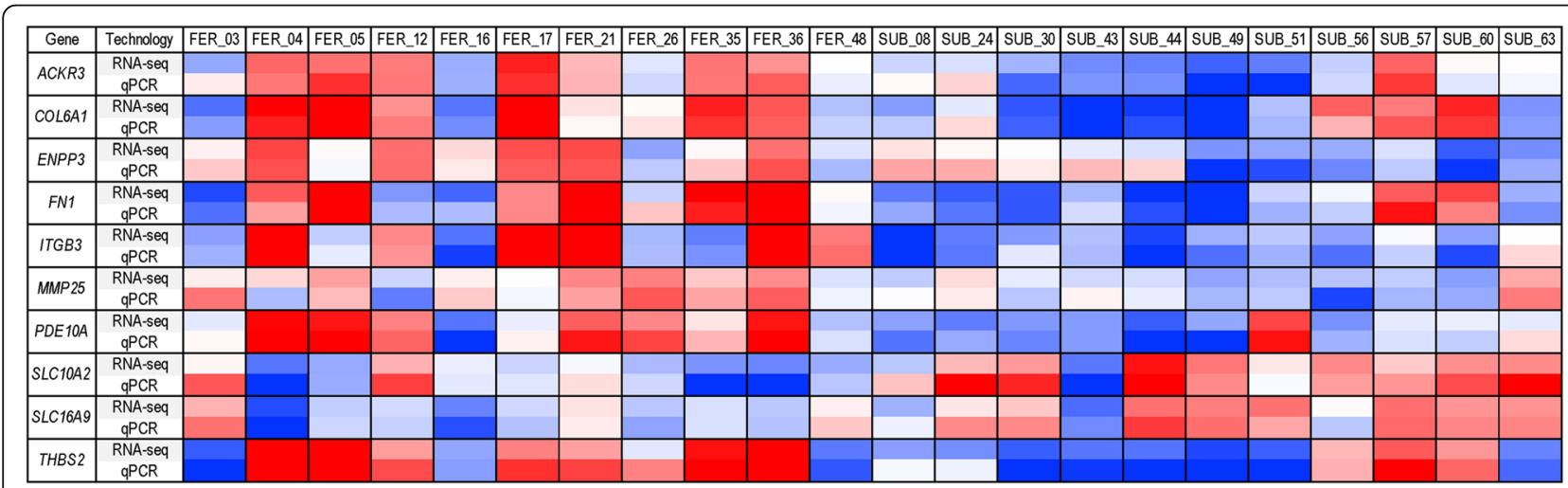

Fig. 4 Confirmation of RNA sequencing results: Heatmap of quantitative real-time RT-PCR and RNA-seq data for ten selected genes. To illustrate correlation of RNA seq and qPCR data relative expression levels (mean-centered log2 expression values) are shown as a heatmap. Red color means higher and blue lower expression levels of the gene compared to the mean of all samples, respectively (from 2 over 0 to -2 ) 
mares compared to cyclic mares during the time of maternal recognition of pregnancy 13.5 days after ovulation. Different DEGs are involved in ECM remodeling and collagen organization. Matrix metallopeptidase 25 (MMP25) and ADAM metallopeptidase with thrombospondin type 1 motif 7 (ADAMTS7), both involved in remodeling and breakdown of ECM, were downregulated in subfertile mares. MMP25 is able to clear the ECM components type IV-collagen, gelatin, fibronectin and fibrin in vitro [47]. The gene $T N X B$ encodes the extracellular matrix glycoprotein tenascin $\mathrm{XB}$. Tenascin plays a role in the organization and formation of elastin and fibrillar collagen in the ECM and is important for tissue structure and elastic fiber stability [48]. Tenascin-deficient women were reported to have a higher risk of complications during pregnancy such as preterm premature rupture of membranes $[49,50]$, but $\operatorname{Tn} x$ knockout mice showed no or only mild pregnancy-related abnormalities [50]. A function of TNXB during estrus regarding fertility was not reported yet. Thrombospondin 2 modulates collagen fibrillogenesis and inhibits angiogenesis [51]. Overall, dysregulations of ECM components involved in focal adhesion could be related to disturbances of endometrial remodeling during the estrous cycle affecting uterine interactions with the embryo and/or sperm.

\section{Immune-related genes downregulated in subfertile mares} Metascape analysis revealed overrepresentation of DEGs related to 'lymphocyte mediated immunity', 'classical pathway of complement activation', 'adaptive immune response' and 'regulation of immune effector process' in genes downregulated in subfertile mares in comparison to fertile mares. At the time of sampling in midestrus, 13 days before insemination, there was no evidence of inflammation neither clinically nor facultative pathogens in the microbial culture or positive findings in the cytological examination in the selected mares for RNA-seq. Marth et al. [25] and Gebhardt et al. [24] described in previous studies that genes associated with immune function are upregulated in the equine uterus during estrus in healthy mares. The authors suspected that the endometrium is preparing for mating during estrus and the required uterine clearance after mating with upregulation of immune-related genes and infiltration by immune cells, respectively. During estrus, the activity of the uterine immune system is increased due to intrauterine inoculation of foreign material such as bacteria, debris and sperm through the open cervix and by mating. A rapid high peak of inflammatory response after invasion of pathogens and a tight balance between pro- and antiinflammatory factors are required to eliminate pathogens and avoid prolonged inflammation [23, 52]. After AI an inflammatory response is important to effectively remove excessive spermatozoa, seminal plasma and other contaminants from the uterus before the embryo reaches the uterus 5-6 days after fertilization [7]. For instance, the innate immune response of mares susceptible to PBIE is altered after breeding or bacterial inoculation, and characterized by abnormal imbalance in proinflammatory and anti-inflammatory cytokines [8, 20, $21,23]$. In our study, the fertile mares with upregulated DEGs related to immune response might therefore be better prepared for these challenges during estrus than the subfertile mares. Clinically or in rectal ultrasound, no differences between the fertile and subfertile mares could be seen in estrus or after insemination. No mares showed prolonged inflammation after insemination in rectal ultrasonic examinations [53]. Also the recently identified diagnostic markers (DEFB1, LYZ, and SLPI) for susceptibility to PBIE were not differentially expressed between subfertile and fertile mares [22], supporting the assumption that subfertility in mares was not due to susceptibility to PBIE. Whereby these diagnostic markers were developed for uterine biopsy samples and not for cytobrush samples. The mRNAs encoding cytokines, which differ in susceptible mares after insemination, were not differentially expressed at estrus in the fertile and subfertile mares.

Different genes encoding proteins involved in activation of lymphocytes were downregulated in subfertile mares. The major histocompatibility complex, class I, A (HLA-A) and linker for activation of $\mathrm{T}$ cells $(L A T)$ have a role in $\mathrm{T}$ cell activation [54]. The genes IGHG1 (LOC102150085, LOC102149846), IGHA1 (LOC106781303), IGHM (LOC100055483), encoding heavy constants of immunoglobulins, and the DEGs cardiotrophin like cytokine factor 1 (CLCF1) and Janus kinase 3 (JAK3) are involved in Bcell activation $[55,56]$. Genes encoding immunoglobulins were also lower expressed in endometrial biopsies of subfertile heifers compared to high fertile heifers on day 14 after estrus [35]. The CLCF1 gene has been found as expressed in the equine adult ovary [56] and in equine endometrium on day 16 of pregnancy [57]. Janus kinase 3 (JAK3) mediates signaling events in innate and adaptive immunity. Mutations in the JAK3 gene leads to severe combined immunodeficiency in humans and mice due to a disturbed T- and B-lymphocyte development and function $[58,59]$. In innate immune cells, JAK3 inhibition was reported to enhance the toll like receptor mediated production of pro-inflammatory cytokines while suppressing the anti-inflammatory cytokine IL10 [60]. Besides immune function, in vitro cultured bovine endometrial cell experiments showed that bovine endometrial cells treated with JAK3 had an increased cell viability, suggesting that JAK3/ STAT pathway may also be involved in cell proliferation in endometrial cells [61].

Another downregulated gene of particular interest is the cytomegalovirus UL 16 binding protein 1 gene (LOC100063831), one DEG from Cluster 2. The human 
orthologue $U L B P 3$ gene encodes a ligand of the immunoreceptor NKG2D, which is mainly expressed by natural killer cells (NK) and T cells [62]. As a ligand of NKG2D of natural NK cells, ULBP stimulates cytokine and chemokine production from NK cells. Furthermore, decidual NK cells play a role in early human and mouse pregnancy by regulation trophoblast invasion and vascularization in the decidua [63-65].

Genes involved in the classical pathway of complement activation were downregulated in uterine cytobrush samples of subfertile mares. The genes $C 1 Q A$ and $C 1 Q B$ encode the A- and B-chain polypeptide of complement component $\mathrm{C} 1 \mathrm{q}$, which is the first component of the classical pathway of complement activation and is activated through binding of immunoglobulins [66]. Genes encoding immunoglobulins were also downregulated in subfertile mares. Besides the function in the complement pathway, $\mathrm{C} 1 \mathrm{q}$ also possesses a physiological role in trophoblast invasion, spiral arteries remodeling and placentation in the mouse [67-69]. C1q-deficient mice showed pregnancy disorders characterized by increased fetal death and signs similar to human pre-eclampsia.

Different genes participating in regulation of innate immune cells showed lower uterine mRNA levels in subfertile mares compared to fertile mares. For instance, phosphatidylinositol-3,4,5-triphosphate dependent Rac exchange factor 1 (Prex1) is strongly expressed in leukocytes and is involved in neutrophil recruitment during inflammation [70]. Besides the function in extracellular matrix remodeling, MMPs also participate in regulation of inflammation and innate immunity for example by activating and degrading chemotactic molecules [71]. Previous studies showed that the expression of several MMPs (MMP1, MMP2, MMP3, MMP7, MMP8, MMP9) was upregulated in the endometrium of mares after inoculation of Streptococcus zooepidemicus or E. coli or after insemination [52, 72]. MMP25, which was differentially expressed between subfertile and fertile mares in our study, has not been described previously in the equine uterus. In mice, Mmp25 expression has been found predominantly in peripheral blood leukocytes. It participates in the regulation of innate immune response. Mmp25-deficient mice are fertile but show a deficiency in their innate immune response [73]. The downregulated $A C K R 3$, also known as CXCR7 or decoy receptor D6, regulates innate and adaptive immunity with his activity as a decoy and scavenger receptor for inflammatory chemokines and thus is involved in the control of inflammation [74]. In mares, $A C K R 3$ is expressed significantly higher in endometrium during estrus compared to diestrus [25] and was increased after inoculation of E. coli [52]. ACKR3 might play a role also in the balancing between protection of the developing embryo and tolerance of its hemiallogeneic tissues [74].
Ackr3-deficient mice showed an earlier and exacerbated inflammatory response in a model of skin inflammation, with high levels of inflammatory chemokines [75]. Although Ackr3-deficient mice were fertile, exposure to LPS or antiphospholipid autoantibodies resulted in higher levels of inflammatory CC chemokines and increased leukocyte infiltrate in placenta, causing an increased rate of fetal loss [76]. The higher level of ACKR3 mRNA expression in fertile mares could affect fertility by preventing an excessive inflammatory response to insemination and might also be important in establishment of pregnancy.

Cysteine rich secretory protein 2 mRNA (CRISP2) was not strongly represented in the uterus samples; nevertheless, a significantly lower level of CRISP2 mRNA was observed in subfertile compared to fertile mares. The gene CRISP2 plays an important role in sperm motility, sperm capacitation and sperm-egg fusion and is positively correlated to male fertility in humans [77], mice [78], and bulls [79]. In stallions, only CRISP3 expression correlates with stallion fertility [80]. Equine CRISP3, highly presented in seminal plasma, suppresses binding between PMNs and viable spermatozoa in the reproductive tract of the mare [81]. Cysteine rich secretory proteins expression and proteins were also found in some studies in the female reproductive tract of mice [82] and humans [83]. In vitro experiments showed that epithelial and neutrophil-derived CRISP3 plays a role in mouse postmenstrual endometrial repair and regeneration and CRISP3 increases adhesion and proliferation of human epithelial cells [83]. To our knowledge, it is the first time that CRSIP2 was described in the equine endometrium. In a recently published study, Klein et al. [57] reported that CRISP3 is expressed in conceptus tissue at day 16 of pregnancy.

Taken together, a variety of genes related to activation of lymphocytes and genes involved in regulation of immune cells were identified as differentially expressed in cytobrush samples of subfertile and fertile mares. These findings could indicate a dysregulation of the immune response in the mares of the subfertile group that might interfere with establishment of pregnancy.

\section{Cytosolic calcium ion concentration related genes downregulated in subfertile mares}

Furthermore, DEGs were found to be involved in 'positive regulation of cytosolic calcium ion concentration' and 'muscle contraction'. Calcium ion mobilization in cells occurs via $\mathrm{Ca}^{2+}$ channels located in the plasma membrane or via intracellular release of calcium from sarcoplasmic reticulum or acidic lysosomal stores [84]. For instance, the DEG SLC8B1 encodes a mitochondrial $\mathrm{Na}^{+} / \mathrm{Ca}^{2+}$ exchanger (NCLX) [85]. The DEG two pore calcium channel 2 (TPCN2) encodes two pore segment channel 2 protein, a key component of the NAADP 
receptor, necessary for NAADP-mediated $\mathrm{Ca}^{2+}$ release from lysosome related organelles [84]. Intracellular $\mathrm{Ca}^{2+}$ release from the sarcoplasmic reticulum occurs via ryanodine receptor, encoded by the DEG RYR1, or inositol 1,4,5-triphospate (IP3)-receptor. Through activation of G protein linked receptor Phospholipase C $ß$ (PLCB2) it hydrolyzes phosphatidylinositol 4,5-biphosphate into diacylglycerol (DAG) and IP3. Increased concentration of IP3 leads to $\mathrm{Ca}^{2+}$ secretion from the sarcoplasmic reticulum [86]. For example, neuromedin U, encoded by the DEG NMU, binds to the G-protein coupled NMU2receptor, which activates Phospholipase $\mathrm{C}$ and has an uterocontractile effect [87]. In accordance with our study, another member of the neuromedin family neuromedin B was upregulated in endometrial biopsy samples of fertile cows compared to infertile ones [32]. The cytosolic calcium concentration controls processes such as metabolism, secretion, fertilization, proliferation, and smooth muscle contraction [88]. Uterine contractility in mares after insemination is important to carry sperm toward the oviduct and to eliminate excessive sperm and contaminants from uterus $[89,90]$.

\section{Genes upregulated in subfertile mares}

Genes upregulated in subfertile mares without clinical signs of uterine diseases compared to fertile mares were mainly related to 'monocarboxylic acid transmembrane transporter activity' (SLC10A2, SLC16A5, SLC16A9) and protein targeting (RPS17, RPL21, TOMM7, 60S ribosomal protein L26-like pseudogene, $40 S$ ribosomal protein S2 pseudogene). Several genes encoding ribosomal proteins were also more abundant in low-fertility heifers compared to high fertility heifers at day 14 post estrus [35].

The gene SLC10A2 encodes a sodium dependent bile acid transporter highly expressed in the liver and intestine [91]. Higher abundance of SLC1OA2 were observed in bovine follicular fluid of lactating cows than in heifers suggesting that increased bile acids within follicular microenvironment may be the reason for fertility problems in lactating cows [92]. The DEGs SLC16A5 and SLC16A9 encode monocarboxylate transporters MCT6 and MCT9. MCT6, highly expressed in placenta and kidney, transports bumetanide, nateglinide, probenecid and PFG2 $\alpha$. The transport of bumetanide is $\mathrm{pH}$ dependent and elevated by extracellular acidic $\mathrm{pH}$ [93, 94]. MCT9 is involved in transport of pyruvic acid, lactic acid and carnitine [95]. The upregulated crystallin lambda 1 gene (CRYL1) is involved in $\beta$ oxidation of fatty acid and the upregulated ELOVL fatty acid elongase 2 (ELOVL2) in elongation of very long fatty acids such as arachidonic acid. Arachidonic acid in turn is a precursor of prostaglandins, which means that ELOVL2 has an influence in prostaglandin metabolism $[96,97]$.
In our study, higher abundance of uterine ELOVL2 seems to have a negative effect on fertility in mares.

\section{Conclusions}

In conclusion, cytobrush samples provide a useful source for comparative uterine transcriptome analysis in the mare, e.g., for biomarker discovery related to subfertility or other uterine diseases. Our study revealed significant differences in the uterine transcriptome at estrus between fertile and subfertile mares without clinical signs of uterine diseases. We have identified a large number of DEGs, which are potential candidates for RNA biomarkers for the prognosis of subfertility in the mare. In further studies, these results have to be validated in a higher number of mares.

\section{Methods}

\section{Mares selected for the study}

The study was conducted between July and October 2018 at a large private commercial stud farm in Mecklenburg-Vorpommern, Germany. In total, 57 German warmblood (Oldenburger, Hannoveraner, Westfale, Mecklenburger) mares aged between 5 and 14 years presented for routinely bacteriological examination before artificial insemination (AI) were selected for the study. Mares with foal as well as barren and maiden mares were represented. To avoid subfertility because of age related modifications of the endometrium only mares until age of 14 were included. All mares showed no clinical signs of reproductive disorders and of PBIE after previous inseminations or had no history of being susceptible to PBIE. From these 57 mares 11 fertile and 11 subfertile mares were selected for comparative transcriptome analysis. The cytobrush sample collection (for detailed description see below) was performed during the routine assessments of uterine health of the mares (such as uterine cytobrush for cytology and swab for bacteriology) owned by the Lewitz Stud, NeustadtGlewe, Germany.

\section{Study design and classification as fertile or subfertile mares}

The 57 mares were initially subdivided according to their breeding history of the breeding season 2018 in mares having their first insemination this year (First Breeders (FB), $n=30$ ) and in mares that failed to conceive after at least two consecutive AI (Repeat Breeders (RB), $n=27$; Fig. 5). During estrus, the reproductive tract of the mares was examined daily by transrectal palpation and ultrasonography (Aloka prosound 2, Hitachi, Japan) to assess the optimal time for sampling and AI and to examine the mares for clinical signs of endometritis including intrauterine fluid, an excessive pattern of endometrial edema, vaginitis, vaginal discharge, abnormal 

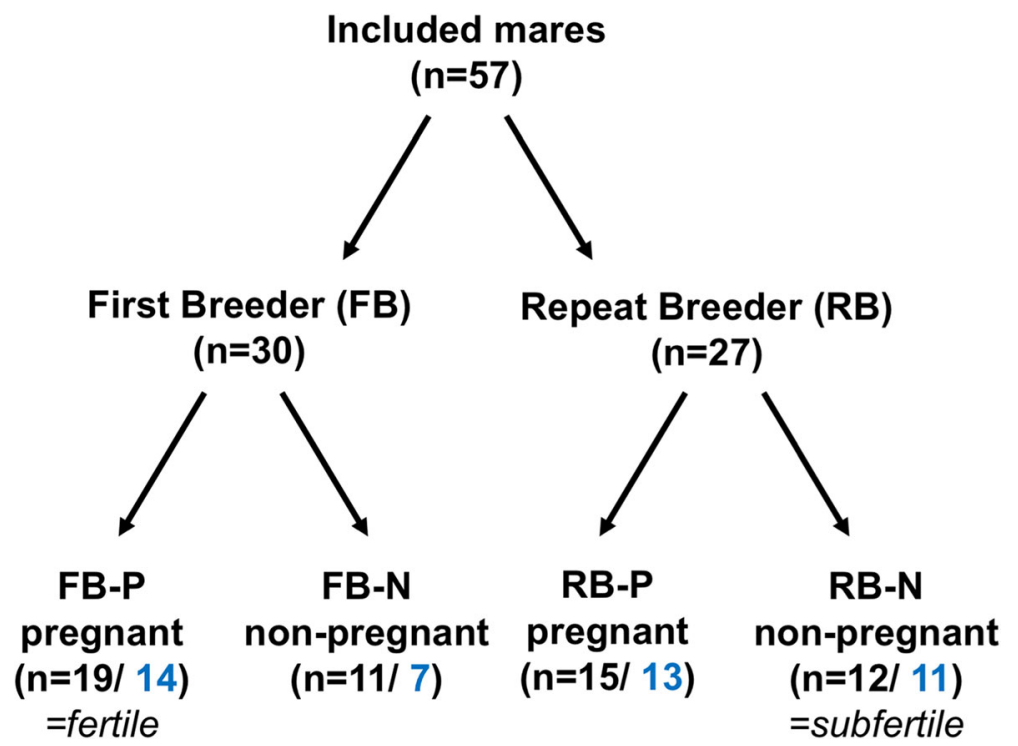

Fig. 5 Grouping of mares according to their breeding history and fertility: First Breeder: uterine samples were taken before first Al during the season; Repeat Breeder = mares failed to conceive after at least two consecutive Als; FB-P= mares pregnant after the first breeding during the season; FB-N = mares not pregnant after the first breeding during the season; $\mathrm{RB}-\mathrm{N}=$ mares pregnant after the third breeding during the season; RB-N = mares not pregnant after at least three breedings during the season; black numbers indicate the total number of mares in each group blue numbers indicate the number of mares after exclusion of mares with facultative pathogenic bacteria in uterine swabs. FB-P were defined fertile, RB-N subfertile. Eleven samples of FB-P and 11 samples of RB-N were used for transcriptome analysis

estrous cycles and cervicitis $[9,98]$. Only mares with no clinical signs for endometritis or reproductive abnormalities were included in the study. Uterine samples were collected as described later from mares in midestrus (dominant follicle $>35 \mathrm{~mm}$, distinct endometrial edema). Ovulation was induced using human chorionic gonadotropin (hCG, Ovogest 1500 I.U. i.v.) when the follicle reached a diameter of $>40 \mathrm{~mm}$ and AI was performed $24 \mathrm{~h}$ later. To avoid subfertility because of low sperm quality, only chilled semen from known fertile stallions having a sperm motility $>50 \%$ were taken. Twenty-four hours after AI, the mares were examined for ovulation and intrauterine fluid by transrectal ultrasound. The first pregnancy diagnosis was carried out 16 days after singleovulations or 14 days after double-ovulations by transrectal ultrasound. A second pregnancy diagnosis was performed $45(+/-2 \mathrm{~d})$ days after ovulation. Mares that were positive in both pregnancy examinations were counted as pregnant. According to the results of the pregnancy examinations, mares were finally grouped into $\mathrm{FB}$ and $\mathrm{RB}$ pregnant (FB-P and RB-P) and not pregnant (FB-N and RB-N). FB-P were considered fertile $(n=19)$ and RB-N were defined subfertile $(n=12$; Fig. 5$)$. Mares with a positive cytological finding or facultative pathogenic bacteria in microbial culture were excluded from further analysis. Eleven mares of the subfertile group (RB-N) with no facultative pathogenic bacteria and negative cytology were used for transcriptome analysis. According to these mares, 11 fertile mares with similar age and reproductive status, negative cytology and without facultative pathogens in microbial culture were selected from the FB-P group for RNA sequencing.

\section{Uterine sample collection}

From the 57 mares, uterine samples were taken in estrus (dominant follicle $>35 \mathrm{~mm}$, distinct endometrial edema). Before sample collection, the rectum was emptied, the tail was wrapped and covered with a glove, the perineum and vulva were cleaned with soap and water and dried with a paper towel. A veterinarian (K.S.W.) wearing a sterile glove inserted manually one double guarded uterine swab (Minitube, Tiefenbach, Germany). After passing the cervix, the inner guard was advanced, and the swab was rolled gently on the endometrium for $15 \mathrm{~s}$. The swab was retracted and removed together with the inner guard from the reproductive tract. The outer guard was left in the reproductive tract to avoid additional manipulation during the following sampling steps. The swab was transferred into Amies medium and sent to a laboratory specialized for bacteriology in equine reproduction (Labor Boese, Harsum, Germany) for conventional microbiological culture. A new inner guard with a cytobrush (Minitube, Tiefenbach, Germany) was inserted through the outer guard into the uterus. The brush was advanced and rolled gently on the endometrium for $15 \mathrm{~s}$. The brush was retracted, removed from the reproductive tract and was inserted directly into a $1.5 \mathrm{ml}$ reaction tube containing $350 \mu \mathrm{l}$ of lysis buffer (AllPrep 
DNA/RNA Kit, Qiagen), rolled for $20 \mathrm{~s}$ and then removed. The reaction tubes were snap-frozen in liquid nitrogen until further analysis. In the same way, a second cytobrush sample was collected. The second cytobrush was rolled onto two microscope slides for cytological examination.

\section{Sample examination}

Cytological examination: After air drying, the microscope slides were stained with Diff-Quick (Diff Quick, Labor+Technik Eberhard Lehmann GmbH, Germany). The slides were evaluated under a light microscope (Olympus Ch-2, Olympus, Tokyo, Japan) as described by Ferris [17]. Briefly, at $400 \mathrm{x}$ magnification, 10 high power fields were analyzed, and the number of neutrophil granulocytes was counted. The presence of neutrophil granulocytes defines the following categories: no granulocytes to rare is a negative finding (healthy), 1-2 granulocytes per field indicates a mild inflammation, 3-5 moderate inflammation, $>5$ severe inflammation [17].

Bacteriological examination: Bacteriological examination was performed at laboratory Böse (Harsum, Germany) specialized for bacteriology in equine reproduction. Bacteria were cultured on Columbia agar with $5 \%$ sheep blood, Columbia CAP Selective agar with sheep blood and Gassner agar (water blue-metachrome yellow- lactose-agar). Additionally, a mycological examination was performed on Sabouraud-Glucose agar with gentamycin and chloramphenicol and on Kimmig-agar. After incubation at $37^{\circ} \mathrm{C}$ for $24 \mathrm{~h}$ and $48 \mathrm{~h}$, the bacterial and fungal growth was evaluated. The aerobic microflora was identified by cultural-biochemical conventional methods and mass spectroscopy (MALDI-TOF). The samples were divided into mild ( $<30$ colonies), moderate ( $30-100$ colonies) and severe ( $>100$ colonies) growth. The bacteriological results were divided into facultative pathogenic bacteria and questionable pathogenic bacteria. Growth of $\beta$-hemolytic Streptococcus, Pseudomonas aeruginosa, Klebsiella pneumoniae, Staphylococcus aureus, Candida albicans, Aspergillus spp. and moderate to severe growth of E. coli were considered as facultative pathogens. Mild growth of E. coli and the growth of other bacteria were considered as questionable pathogens. Samples with facultative pathogens were excluded from further analysis $(n=12)$.

\section{Extraction of RNA and estimation of concentration and quality}

The total RNA extraction was performed with the AllPrep DNA/RNA micro kit (Qiagen, Hilden, Germany) according to the manufacturer's instructions using the protocol of Simultaneous Purification of Genomic DNA and Total RNA from Animal and Human Tissues. Because of rolling the cytobrush directly in lysis buffer after taking the sample, the initial start of the protocol was at step three of the protocol. RNA and DNA were extracted according to manufacturer's instructions, instead of step 7 steps F1-F4 were used. RNA was eluted after two five-minute incubations with $14 \mu \mathrm{l}$ of RNase-free water.

The total RNA concentration and purity were measured by spectrophotometry (Nano Drop One, Thermo Scientific). The quality of the isolated total RNA was assessed using the Agilent 2100 Bioanalyzer RNA 6000 Nano assay (Agilent Technologies, Waldbronn, Germany).

\section{RNA-sequencing and data analysis}

For Illumina RNA-sequencing, 11 samples of subfertile mares (RB-N) and 11 of the fertile mares (FB-P) were selected. The isolated RNA was used for standard Illumina messenger RNA sequencing following the TrueSeq stranded mRNA protocol, which was performed by the Functional Genomic Center Zürich. The samples were barcoded and pooled and the pool was sequenced on an Illumina NovaSeq 6000 (100 bp single-end reads).

The data analysis of the resulting fastq files was performed on a local Galaxy server installation [99, 100]. In Galaxy, as first step and after every fastq file processing step, 'Fast QC' and 'Multi QC' were used to control the quality of the data and the processing steps. At first, 'Trim Galore' was used to trim adapter sequences, low quality ends and to discard reads shorter than $50 \mathrm{bp}$. To map the reads to the annotated equine genome equCab 3.0 downloaded from the National Center for Biotechnology Information (NCBI), the tool 'HISAT2' [101] was used. With the tool 'Feature Counts', the number of RNA sequence reads for the annotated genes were counted considering the strand specificity of the reads. 'Column Join on data' was used to build a count table containing all samples. This count table was filtered to remove genes with negligible read counts by using the counts per million (CPM) per sample filtering tool [102]. The mean library size and potential CPM cutoff (Counttable statistics, custom Galaxy tool) were calculated and the cutoff set to $1.09 \mathrm{CPM}$ (corresponding to an average of 20 reads per library) for at least 5 out of the 22 libraries. The filtered count table was used in the statistical program $R$ with the package edge $R$ [103] for the identification of differentially expressed genes (DEGs) between subfertile and fertile mares. Genes with an adjusted $P$ value (false discovery rate, FDR) lower than 0.01 (FDR $10 \%)$ were considered as differentially expressed.

The web tool MAdb (Gene Symbol match, Ensembl compara database release 95, Blast) (https://madb.ethz. $\mathrm{ch} /$ ) [104] was used to obtain the corresponding human gene symbols and gene information for the DEGs. Hierarchical clustering of DEGs was performed with the HCL tool of Multi Experiment Viewer (MeV) [105]. Metascape enrichment analysis program (http:// metascape.org) [106] was used for identification of overrepresented functional categories and pathways of the 
DEGs. The annotation and enrichment analyses were performed separately for genes upregulated or downregulated in subfertile mares compared to fertile mares based on the corresponding human NCBI gene IDs.

The RNA-seq data presented in this study are openly available at NCBI's Sequence Read Archive (SRA) under the BioProject accession PRJNA667444.

\section{Quantitative real-time RT-PCR}

The same RNA samples (400 ng total RNA) as used for RNA sequencing were reverse transcribed into firststrand cDNA using the RNA to cDNA EcoDry ${ }^{\text {mit }}$ (Double Primed) Premix (Takara Bio Company, USA). The cDNA samples were diluted with RNase/DNase-free water to a total volume of $40 \mu \mathrm{l}$.

To validate RNA sequencing results, ten DEGs with known gene symbols and with potential role in fertility were selected from the most significantly enriched
Metascape categories for quantitative real-time RT-PCR. The DEGs solute carrier family 10 member 2 (SLC1OA2), solute carrier family 16 member 9 (SLC16A9), integrin subunit beta 3 (ITGB3), collagen type 6 alpha 1 chain (COL6A1), thrombospondin 2 (THBS2), fibronectin 1 (FN1), matrix metallopeptidase 25 (MMP25), ectonucleotide pyrophosphatase/phosphodiesterase 3 (ENPP3), atypical chemokine receptor 3 (ACKR3) and phosphodiesterase $10 \mathrm{~A}$ (PDE10A) were selected. The mapping of RNA sequencing reads for these genes were checked with Integrated Genomics Viewer (IGV) [107] and matching primers were designed using Primer-Blast (NCBI) [108]. The primer sequences (ordered from Integrated DNA Technology, Leuven, Belgium) and their annealing temperatures are listed in Table 5 .

The mRNA expression of the selected genes was measured by real-time PCR on a Light Cycler 96 (Roche, Mannheim, Germany) with the KAPA HiFi HotStart

Table 5 Primers used for quantitative real-time RT-PCR. Primers were designed using NCBI's Primer BLAST. Ten DEGs were selected to validate RNA-sequencing results by qRT-PCR. ACTB, GAPDH and $18 \mathrm{~S}$ rRNA were used as reference genes. The designed primers are listed with product length and annealing temperature. $F$ forward primer, $R$ reverse primer

\begin{tabular}{|c|c|c|c|c|}
\hline Gene & Primer sequence $5^{\prime}-3^{\prime}$ & Product length (bp) & Annealing Temp $\mathrm{C}^{\circ}$ & $\begin{array}{l}\text { Accession no./reference } \\
\text { of target transcript }\end{array}$ \\
\hline \multirow[t]{2}{*}{ SLC1OA2 } & F: ATCGTTCACCTACGAGGAGC & 191 & 66 & XM_001493450.3 \\
\hline & R: TCACCTTGTGGAGCGATGAC & & & \\
\hline \multirow[t]{2}{*}{ SLC16A9 } & F: TGTTCTITGCTGGGCTTGGA & 110 & 68 & XM_023643589.1 \\
\hline & R: CAGGACGCAGAAGCCACTAA & & & \\
\hline \multirow[t]{2}{*}{ ITGB3 } & F: GCACCCGTTACTGTCGTGAT & 145 & 65 & NM_001081802.1 \\
\hline & R: AGGATGGACTTTCCACTGGC & & & \\
\hline \multirow[t]{2}{*}{ THBS2 } & F: TGGCTGGAAAGACTACACCG & 107 & 65 & NM_001163117.2 \\
\hline & R: CTGAATCCGCCATGACCTGT & & & \\
\hline \multirow[t]{2}{*}{ FN1 } & F: GGTCGTTACTGTGGGCAACT & 101 & 65 & XM_023642280.1 \\
\hline & R: CCTCTCCGATGGCGTAATGG & & & \\
\hline \multirow[t]{2}{*}{ COL6A1 } & F: CCTCCTGGGATAAACGGCAC & 184 & 65 & XM_001488351.5 \\
\hline & R: ACTCGTCCATCTCTGGTCGT & & & \\
\hline \multirow[t]{2}{*}{ ACKR3 } & F: ATGCCTGAGTAGCCTGGAGA & 113 & 65 & XM_023642191.1 \\
\hline & R: GTCCTGTGGTGATGCAAACG & & & \\
\hline \multirow[t]{2}{*}{ LOC100073089 (ENPP3) } & F: TAGAATACGTGGTCAACACCAG & 190 & 68 & XM_023651094.1 \\
\hline & R: TCAACCCAGTTGGCTTCCTG & & & \\
\hline \multirow[t]{2}{*}{ PDEIOA } & F: GCGTGAATTGTAGCAGCCAG & 76 & 65 & XM_023633145.1 \\
\hline & R: ACTGATTGCAGAAAGACACTTCC & & & \\
\hline \multirow[t]{2}{*}{ MMP25 } & F: ATGTCACCGTCAGCAACACAG & 189 & 70 & XM_023633145.1 \\
\hline & R: GTCCAGGCTTGAGAGTGGCT & & & \\
\hline \multirow[t]{2}{*}{ ACTB } & F: TCCCAGCACGATGAAGATCAA & 189 & 68 & XM_023655002.1 \\
\hline & R: GGTGGATCGCACTAACAGT & & & \\
\hline \multirow[t]{2}{*}{ GAPDH } & F: ATTGCCCTCAACGACCACTT & 140 & 70 & NM_001163856.1 \\
\hline & R: TCTTGCTGGGTGATTGGTGG & & & \\
\hline \multirow[t]{2}{*}{185 rRNA } & F: GCGTGTGCCTACCCTACGCC & 165 & 68 & AJ311673.1/ [24] \\
\hline & R: ATCGTTCACCTACGAGGAGC & & & \\
\hline
\end{tabular}


PCR Kit (Roche, Kapa Biosystems Pty, South Africa) adding EvaGreen ${ }^{\circ}$ Dye, 20x in water (Biotium). The qPCR was performed in a reaction volume of $10 \mu \mathrm{l}$, consisting of $2 \mu \mathrm{l} 5 \mathrm{x}$ Kapa HiFi Buffer, $0.3 \mu \mathrm{l}$ Kapa dNTP mix (0.3 mM each), $0.2 \mu \mathrm{l}$ Kapa HiFi HotStart DNA polymerase, $0.3 \mu \mathrm{l}$ of each primer $(10 \mu \mathrm{M}), 0.5 \mu \mathrm{l}$ Eva Green Dye, $5.4 \mu \mathrm{l}$ water and $1 \mu \mathrm{l} \mathrm{cDNA}$ template. Cycle parameters of the PCR were $95^{\circ} \mathrm{C}$ for $3 \mathrm{~min}$, followed by 45 cycles of $98^{\circ} \mathrm{C}$ for $20 \mathrm{~s}$, specific annealing temperature for $15 \mathrm{~s}$ and $72{ }^{\circ} \mathrm{C}$ for $15 \mathrm{~s}$, and then a melting step $\left(95^{\circ} \mathrm{C}\right.$ for $10 \mathrm{~s}, 65^{\circ} \mathrm{C}$ for $60 \mathrm{~s}$ and $97^{\circ} \mathrm{C}$ for $1 \mathrm{~s}$ ). Melting curves of the amplified PCR products were obtained for confirmation of specific amplification. A no-template control (RNA sample) was included for each primer pair. The $C_{q}$ (quantification cycle) values determined for the target genes were normalized against the geometric mean of the reference genes beta actin (ACTB), glyceraldehyde-3-phosphate dehydrogenase (GAPDH) and $18 \mathrm{~S}$ rRNA [109]. Relative expression differences between subfertile and fertile mares were calculated, and a t-test was performed in Microsoft Excel. $P$-values $<0.05$ were considered significant.

\begin{abstract}
Abbreviations
Al: Artificial insemination; CPM: Counts per million; DEG: Differentially expressed gene; DNA: Deoxyribonucleic acid; CDNA: Complementary DNA; ECM: Extracellular matrix; FB: First Breeders; FB-P: First Breeder-pregnant; FBN: First Breeder-not pregnant; FDR: False discovery rate; i.v: Intravenous; KEGG: Kyoto Encyclopedia of Genes and Genomes; Log2 FC: Log2-foldchange; mRNA: Messenger ribonucleic acid; NCBI: National Center for Biotechnology Information; NAADP: Nicotinic acid adenine dinucleotide phosphate; NKG2D: Natural Killer Group 2D; PBIE: Persistent breedinginduced endometritis; RB: Repeat Breeders; RB-P: Repeat Breeder- pregnant; RB-N: Repeat Breeder- not pregnant; RIN: RNA integrity number; RNA: Ribonucleic acid; RNA-seq: RNA sequencing; RT-PCR: Reverse transcription- Polymerase Chain Reaction; qRT-PCR: Quantitative RT-PCR
\end{abstract}

\section{Supplementary Information}

The online version contains supplementary material available at https://doi. org/10.1186/s12864-021-07701-3.

Additional file 1. Differentially expressed genes (DEGs) in cytobrush samples collected from subfertile vs. fertile mares.

Additional file 2. Metascape enrichment analysis results of transcripts downregulated or upregulated in cytobrush samples collected from subfertile vs. fertile mares.

\section{Acknowledgments}

We would like to acknowledge the great technical support of the laboratory work by Siyka Bozukova. Furthermore, we like to thank the Lewitz stud for the possibility to collect samples for the study. Additionally, we thank to laboratory Böse for performing bacteriological examination and the Functional Genomics Center Zurich (FGCZ) for performing Illumina sequencing.

\section{Authors' contributions}

K.S.W. performed the sample collection, isolation of RNA, RNA-seq data analysis, GPCR validation, and was a major contributor in writing the manuscript; K.W. supported mare and sample selection and data interpretation and writing; M.B. contributed to the design of the sample collection procedure, the selection of the mares owned by the Lewitz Stud for the study, and to sample collection; S.B. contributed to the study design, supervised all molecular biology laboratory analyses, supervised and performed part of the data analysis, supervision of study performance, manuscript writing and editing; H.B. study design, supported design of sample collection procedure, supervision of study performance; all authors read and approved the final manuscript.

\section{Funding}

This research was funded by Foundation Pro Pferd Zurich (Project 2018-03).

\section{Availability of data and materials}

The datasets generated during the current study are in this published article and the RNA-seq data are openly available at NCBI's Sequence Read Archive (SRA) under the BioProject accession PRJNA667444 https://www.ncbi.nlm.nih. gov/sra/?term=PRJNA667444.

\section{Declarations}

Ethics approval and consent to participate

The samples were taken as part of routine diagnostics and therefore did not require an animal experiment permit.

\section{Consent for publication}

Not applicable.

\section{Competing interests}

The authors declare that they have no competing interests. Stefan Bauersachs is serving as Associate Editor for BMC Genomics was realized.

\section{Author details}

${ }^{1}$ Clinic of Reproductive Medicine, Department for Farm Animals, Vetsuisse Faculty Zurich, University of Zurich, Lindau (ZH), Switzerland. ${ }^{2}$ Present address: Department for Farm Animals and Veterinary Public Health, Clinical Unit for Herd Health Management in Ruminants, University of Veterinary Medicine, Vienna, Austria. ${ }^{3}$ The Lewitz Stud, Neustadt-Glewe, Germany. ${ }^{4}$ Institute of Veterinary Anatomy, Vetsuisse Faculty Zurich, University of Zurich, Lindau $(\mathrm{ZH})$, Switzerland.

Received: 17 December 2020 Accepted: 11 May 2021

Published online: 22 May 2021

\section{References}

1. Riddle WT, LeBlanc MM, Stromberg AJ. Relationships between uterine culture, cytology and pregnancy rates in a thoroughbred practice. Theriogenology. 2007;68(3):395-402. https://doi.org/10.1016/j. theriogenology.2007.05.050.

2. Waelchli RO. Endometrial biopsy in mares under nonuniform breeding management conditions: prognostic value and relationship with age. Can Vet J. 1990:31(5):379-84.

3. Kareskoski M, Venhoranta H, Virtala AM, Katila T. Analysis of factors affecting the pregnancy rate of mares after inseminations with cooled transported stallion semen. Theriogenology. 2019;127:7-14. https://doi.org/10.1016/j. theriogenology.2018.12.036.

4. Morris LHA, Allen WR. Reproductive efficiency of intensively managed thoroughbred mares in Newmarket. Equine Vet J. 2002;34(1):51-60. https:// doi.org/10.2746/042516402776181222.

5. Traub-Dargatz JL, Salman MD, Voss JL. Medical problems of adult horses, as ranked by equine practitioners. J Am Vet Med Assoc. 1981;198(10):1745-7.

6. LeBlanc MM. Advances in the diagnosis and treatment of chronic infectious and post-mating-induced endometritis in the mare. Reprod Domest Anim. 2010;45(Suppl 2):21-7. https://doi.org/10.1111/j.1439-0531.2010.01634.x.

7. Christoffersen $M$, Troedsson M. Inflammation and fertility in the mare. Reprod Domest Anim. 2017;52(Suppl 3):14-20. https://doi.org/10.1111/ rda.13013.

8. Woodward EM, Christoffersen M, Campos J, Betancourt A, Horohov D, Scoggin KE, et al. Endometrial inflammatory markers of the early immune response in mares susceptible or resistant to persistent breeding-induced endometritis. Reproduction. 2013;145(3):289-96. https://doi.org/10.1530/ REP-12-0452.

9. LeBlanc MM, Causey RC. Clinical and subclinical endometritis in the mare: both threats to fertility. Reprod Domest Anim. 2009:44(Suppl 3):10-22. https://doi.org/10.1111/j.1439-0531.2009.01485.x. 
10. Nielsen JM. Endometritis in the mare: a diagnostic study comparing cultures from swab and biopsy. Theriogenology. 2005;64(3):510-8. https://doi.org/1 0.1016/j.theriogenology.2005.05.034.

11. LeBlanc MM, Magsig J, Stromberg AJ. Use of a low-volume uterine flush for diagnosing endometritis in chronically infertile mares. Theriogenology. 2007; 68(3):403-12. https://doi.org/10.1016/j.theriogenology.2007.04.038.

12. Christoffersen M, Brandis L, Samuelsson J, Bojesen AM, Troedsson MH, Petersen MR. Diagnostic double-guarded low-volume uterine lavage in mares. Theriogenology. 2015;83(2):222-7. https://doi.org/10.1016/j. theriogenology.2014.09.008.

13. Buczkowska J, Kozdrowski R, Nowak M, Ras A, Staroniewicz Z, Siemieniuch MJ. Comparison of the biopsy and cytobrush techniques for diagnosis of subclinical endometritis in mares. Reprod Biol Endocrinol. 2014;12(1):27. https://doi.org/10.1186/1477-7827-12-27.

14. Kenney RM, Doig PA. Equine endometrial biopsy. In: Current Therapy in Theriogenology. 2nd ed. Philadelphia: Morrow, DA, Saunders, WB; 1986. p. 723-9.

15. Overbeck W, Witte TS, Heuwieser W. Comparison of three diagnostic methods to identify subclinical endometritis in mares. Theriogenology. 2011;75(7):1311-8. https://doi.org/10.1016/j.theriogenology.2010.12.002.

16. Singh J, Behal A, Singla N, Joshi A, Birbian N, Singh S, et al. Metagenomics: concept, methodology, ecological inference and recent advances. Biotechnol J. 2009;4(4):480-94. https://doi.org/10.1002/biot.2 00800201

17. Ferris RA. Endometritis: diagnostic tools for infectious Endometritis. Vet Clin North Am Equine Pract. 2016;32(3):481-98. https://doi.org/10.1016/j.cveq.201 6.08.001.

18. Rhoads DD, Cox SB, Rees EJ, Sun Y, Wolcott RD. Clinical identification of bacteria in human chronic wound infections: culturing vs. 165 ribosomal DNA sequencing. BMC Infect Dis. 2012;12:321.

19. Nielsen JM, Troedsson MH, Pedersen MR, Bojesen AM, Lehn-Jensen H, Zent WW. Diagnosis of endometritis in the mare based on bacteriological and cytological examinations of the endometrium: comparison of results obtained by swabs and biopsies. J Equine Vet Sci. 2010;30(1):27-30. https:// doi.org/10.1016/j.jevs.2009.11.006.

20. Fumuso E, Giguère S, Wade J, Rogan D, Videla-Dorna I, Bowden RA Endometrial IL-1 $\beta, I L-6$ and TNF-a, mRNA expression in mares resistant or susceptible to post-breeding endometritis. Vet Immunol Immunopathol. 2003;96(1-2):31-41. https://doi.org/10.1016/S0165-2427(03)00137-5.

21. Fumuso E, Aguilar J, Giguère S, David O, Wade J, Rogan D. Interleukin-8 (IL8) and 10 (IL-10) mRNA transcriptions in the endometrium of normal mares and mares susceptible to persistent post-breeding endometritis. Effects of estrous cycle, artificial insemination and immunomodulation. Anim Reprod Sci. 2006;94(1-4):282-5.

22. Marth CD, Firestone SM, Hanlon D, Glenton LY, Browning GF, Young $N D$, et al. Innate immune genes in persistent mating-induced endometritis in horses. Reprod Fertil Dev. 2018;30(3):533-45. https://doi. org/10.1071/RD17157.

23. Christoffersen M, Woodward E, Bojesen AM, Jacobsen S, Petersen MR, Troedsson $\mathrm{MH}$, et al. Inflammatory responses to induced infectious endometritis in mares resistant or susceptible to persistent endometritis. BMC Vet Res. 2012;8(1):41. https://doi.org/10.1186/1746-6148-8-41.

24. Gebhardt S, Merkl M, Herbach N, Wanke R, Handler J, Bauersachs S. Exploration of global gene expression changes during the estrous cycle in equine endometrium. Biol Reprod. 2012;87(6):136. https://doi.org/10.1095/ biolreprod.112.103226

25. Marth CD, Young ND, Glenton LY, Noden DM, Browning GF, Krekeler N. Effect of ovarian hormones on the healthy equine uterus: a global gene expression analysis. Reprod Fertil Dev. 2015;28(11):1810-24. https://doi.org/1 $0.1071 /$ RD 14513

26. Bersinger NA, Wunder DM, Birkhauser MH, Mueller MD. Gene expression in cultured endometrium from women with different outcomes following IVF. Mol Hum Reprod. 2008;14(8):475-84. https://doi.org/10.1 093/molehr/gan036.

27. Othman R, Omar MH, Shan LP, Shafiee MN, Jamal R, Mokhtar NM. Microarray profiling of secretoryphase endometrium from patients with recurrent miscarriage. Reprod Biol. 2012;12(2):183-99. https://doi.org/10.101 6/S1642-431X(12)60085-0.

28. Tapia A, Gangi LM, Zegers-Hochschild F, Balmaceda J, Pommer R, Trejo L, et al. Differences in the endometrial transcript profile during the receptive period between women who were refractory to implantation and those who achieved pregnancy. Hum Reprod. 2008;23(2):340-51. https://doi.org/1 0.1093/humrep/dem319.

29. Altmae S, Martinez-Conejero JA, Salumets A, Simon C, Horcajadas JA, Stavreus-Evers A. Endometrial gene expression analysis at the time of embryo implantation in women with unexplained infertility. Mol Hum Reprod. 2010;16(3):178-87. https://doi.org/10.1093/molehr/gap102.

30. Koler M, Achache $H$, Tsafrir A, Smith Y, Revel A, Reich R. Disrupted gene pattern in patients with repeated in vitro fertilization (IVF) failure. Hum Reprod. 2009;24(10):2541-8. https://doi.org/10.1093/humrep/dep193.

31. Wagener $K$, Pothmann $H$, Prunner I, Peter S, Erber R, Aurich C, et al. Endometrial mRNA expression of selected pro-inflammatory factors and mucins in repeat breeder cows with and without subclinical endometritis. Theriogenology. 2017;90:237-44. https://doi.org/10.1016/j.theriogenology.2 016.12.013.

32. Moran B, Butler ST, Moore SG, MacHugh DE, Creevey CJ. Differential gene expression in the endometrium reveals cytoskeletal and immunological genes in lactating dairy cows genetically divergent for fertility traits. Reprod Fertil Dev. 2017;29(2):274-82. https://doi.org/10.1071/RD15128.

33. Moraes JGN, Behura SK, Geary TW, Hansen PJ, Neibergs HL, Spencer TE. Uterine influences on conceptus development in fertility-classified animals. Proc Natl Acad Sci U S A. 2018;115(8):E1749-58. https://doi.org/10.1073/pna S.1721191115

34. Moore SG, Pryce JE, Hayes BJ, Chamberlain AJ, Kemper KE, Berry DP, et al. Differentially expressed genes in endometrium and Corpus Luteum of Holstein cows selected for high and low fertility are enriched for sequence variants associated with fertility. Biol Reprod. 2016;94(1):19. https://doi.org/1 0.1095/biolreprod.115.132951.

35. Geary TW, Burns GW, Moraes JGN, Moss Jl, Denicol AC, Dobbs KB, et al. Identification of beef heifers with superior uterine capacity for pregnancy. Biol Reprod. 2016;95(2):47. https://doi.org/10.1095/biolreprod.116.141390.

36. Ghasemi F, Gonzalez-Cano P, Griebel PJ, Palmer C. Proinflammatory cytokine gene expression in endometrial cytobrush samples harvested from cows with and without subclinical endometritis. Theriogenology. 2012;78(7):153847. https://doi.org/10.1016/j.theriogenology.2012.06.022.

37. Kanehisa M, Goto S. KEGG: Kyoto encyclopedia of genes and genomes. Nucleic Acids Res. 2000;28(1):27-30. https://doi.org/10.1093/nar/28.1.27.

38. Cardoso B, Oliveira ML, Pugliesi G, Batista E, Binelli M. Cytobrush: a tool for sequential evaluation of gene expression in bovine endometrium. Reprod Domest Anim. 2017;52(6):1153-7. https://doi.org/10.1111/rda.13037.

39. Scaravaggi I, Borel N, Romer R, Imboden I, Ulbrich SE, Zeng S, et al. Cell type-specific endometrial transcriptome changes during initial recognition of pregnancy in the mare. Reprod Fertil Dev. 2019:31(3):496-508. https://doi. org/10.1071/RD18144

40. Killeen AP, Morris DG, Kenny DA, Mullen MP, Diskin MG, Waters SM. Global gene expression in endometrium of high and low fertility heifers during the mid-luteal phase of the estrous cycle. BMC Genomics. 2014;15:234.

41. Iwahashi M, Muragaki $Y$, Ooshima A, Yamoto M, Nakano R. Alterations in distribution and composition of the extracellular matrix during decidualization of the human endometrium. J Reprod Fertil. 1996;108(1): 147-55. https://doi.org/10.1530/jrf.0.1080147.

42. Lessey BA, Castelbaum AJ, Sawin SW, Sun J. Integrins as markers of uterine receptivity in women with primary unexplained infertility. Fertil Steril. 1995; 63(3):535-42. https://doi.org/10.1016/S0015-0282(16)57422-6.

43. Illera MJ, Cullinan E, Gui Y, Yuan L, Beyler SA, Lessey BA. Blockade of the alpha(v)beta (3) integrin adversely affects implantation in the mouse. Biol Reprod. 2000;62(5):1285-90. https://doi.org/10.1095/biolreprod62.5.1285.

44. Germeyer A, Savaris RF, Jauckus J, Lessey B. Endometrial beta3 integrin profile reflects endometrial receptivity defects in women with unexplained recurrent pregnancy loss. Reprod Biol Endocrinol. 2014;12(1):53. https://doi. org/10.1186/1477-7827-12-53.

45. Aliagas E, Vidal A, Torrejón-Escribano B, Taco Mdel R, Ponce J, de Aranda IG, et al. Ecto-nucleotidases distribution in human cyclic and postmenopausic endometrium. Purinergic Signal. 2013;9(2):227-37. https://doi.org/10.1007/ s11302-012-9345-0.

46. Klein C, Scoggin KE, Ealy AD, Troedsson MH. Transcriptional profiling of equine endometrium during the time of maternal recognition of pregnancy. Biol Reprod. 2010;83(1):102-13. https://doi.org/10.1095/ biolreprod.109.081612.

47. English WR, Velasco G, Stracke JO, Knäuper V, Murphy G. Catalytic activities of membrane-type 6 matrix metalloproteinase (MMP25). FEBS Lett. 2001; 491(1-2):137-42. https://doi.org/10.1016/S0014-5793(01)02150-0. 
48. Petersen JW, Douglas JY. Tenascin-X, collagen, and Ehlers-Danlos syndrome: tenascin-X gene defects can protect against adverse cardiovascular events. Med Hypotheses. 2013;81(3):443-7. https://doi. org/10.1016/j.mehy.2013.06.005.

49. Anum EA, Hill LD, Pandya A, Strauss JF 3rd. Connective tissue and related disorders and preterm birth: clues to genes contributing to prematurity. Placenta. 2009;30(3):207-15. https://doi.org/10.1016/j.placenta.2008.12.007.

50. Egging DF, van Vlijmen-Willems I, Choi J, Peeters AC, van Rens D, Veit G, et al. Analysis of obstetric complications and uterine connective tissue in tenascin-X-deficient humans and mice. Cell Tissue Res. 2008;332(3):523-32. https://doi.org/10.1007/s00441-008-0591-y.

51. Bornstein P, Kyriakides TR, Yang Z, Armstrong LC, Birk DE. Thrombospondin 2 modulates collagen fibrillogenesis and angiogenesis. J Investig Dermatol Symp Proc. 2000;5(1):61-6. https://doi.org/10.1046/j.1087-0024.2000.00005.x.

52. Marth CD, Young ND, Glenton LY, Noden DM, Browning GF, Krekeler N. Deep sequencing of the uterine immune response to bacteria during the equine oestrous cycle. BMC Genomics. 2015;16(1):934. https://doi.org/10.11 86/s12864-015-2139-3.

53. Canisso IF, Stewart J, Coutinho da Silva MA. Endometritis: managing persistent post-breeding Endometritis. Vet Clin North Am Equine Pract. 2016;32(3):465-80. https://doi.org/10.1016/j.cveq.2016.08.004.

54. Zhang W, Sommers CL, Burshtyn DN, Stebbins CC, DeJarnette JB, Trible RP, et al. Essential role of LAT in T cell development. Immunity. 1999;10(3):32332. https://doi.org/10.1016/S1074-7613(00)80032-1.

55. Senaldi G, Stolina M, Guo J, Faggioni R, McCabe S, Kaufman SA, et al. Regulatory effects of novel neurotrophin-1/b cell-stimulating factor-3 (cardiotrophin-like cytokine) on B cell function. J Immunol. 2002;168(11): 5690-8. https://doi.org/10.4049/jimmunol.168.11.5690.

56. Hall SE, Upton RMO, MCLaughlin EA, Sutherland JM. Phosphoinositide 3kinase/protein kinase B (PI3K/AKT) and Janus kinase/signal transducer and activator of transcription (JAK/STAT) follicular signalling is conserved in the mare ovary. Reprod Fertil Dev. 2018;30(4):624-33. https://doi.org/10.1071/ RD17024.

57. Klein C. Novel equine conceptus? Endometrial interactions on day 16 of pregnancy based on RNA sequencing. Reprod Fertil Dev. 2015.

58. Macchi P, Villa A, Giliani S, Sacco MG, Frattini A, Porta F, et al. Mutations of Jak-3 gene in patients with autosomal severe combined immune deficiency (SCID). Nature. 1995;377(6544):65-8. https://doi.org/10.1038/377065a0.

59. Thomis DC, Gurniak CB, Tivol E, Sharpe AH, Berg L. Defects in B lymphocyte maturation and T lymphocyte activation in mice lacking Jak3. Science. 1995;270(5237):794-7. https://doi.org/10.1126/science.270.5237.794.

60. Wang H, Brown J, Gao S, Liang S, Jotwani R, Zhou H, et al. The role of JAK-3 in regulating TLR-mediated inflammatory cytokine production in innate immune cells. J Immunol. 2013;191(3):1164-74. https://doi.org/10.4049/ jimmunol.1203084.

61. Ndiaye K, Castonguay A, Benoit G, Silversides DW, Lussier JG. Differential regulation of Janus kinase 3 (JAK3) in bovine preovulatory follicles and identification of JAK3 interacting proteins in granulosa cells. J Ovarian Res. 2016:9(1):71. https://doi.org/10.1186/s13048-016-0280-5.

62. Cosman D, Müllberg J, Sutherland C, Chin W, Armitage R, Fanslow W, et al ULBPs, novel MHC class I-related molecules, bind to CMV glycoprotein UL16 and stimulate NK cytotoxicity through the NKG2D receptor. Immunity. 2001; 14(2):123-33. https://doi.org/10.1016/S1074-7613(01)00095-4.

63. Xie X, He H, Colonna M, Seya T, Takai T, Croy BA. Pathways participating in activation of mouse uterine natural killer cells during pregnancy. Biol Reprod. 2005;73(3):510-8. https://doi.org/10.1095/ biolreprod.104.033951

64. Marlin R, Duriez M, Berkane N, de Truchis C, Madec Y, Rey-Cuille MA, et al. Dynamic shift from CD85j/ILT-2 to NKG2D NK receptor expression pattern on human decidual NK during the first trimester of pregnancy. PLoS One. 2012;7(1):e30017. https://doi.org/10.1371/journal.pone.0030017.

65. Hanna J, Goldman-Wohl D, Hamani Y, Avraham I, Greenfield C, NatansonYaron S, et al. Decidual NK cells regulate key developmental processes at the human fetal-maternal interface. Nat Med. 2006;12(9):1065-74. https:// doi.org/10.1038/nm1452

66. Kishore U, Reid KBM. C1q:structure, function, and receptors. Immunopharmacology. 2000;49(1-2):159-70. https://doi.org/10.1016/S01 62-3109(00)80301-X.

67. Singh J, Ahmed A, Girardi G. Role of complement component C1q in the onset of preeclampsia in mice. Hypertension. 2011;58(4):716-24. https://doi. org/10.1161/HYPERTENSIONAHA.111.175919.
68. Agostinis C, Bulla R, Tripodo C, Gismondi A, Stabile H, Bossi F, et al. An alternative role of $\mathrm{Clq}$ in cell migration and tissue remodeling: contribution to trophoblast invasion and placental development. J Immunol. 2010;185(7): 4420-9. https://doi.org/10.4049/jimmunol.0903215.

69. Agostinis C, Tedesco F, Bulla R. Alternative functions of the complement protein C1q at embryo implantation site. J Reprod Immunol. 2017;119:7480. https://doi.org/10.1016/j.jri.2016.09.001.

70. Dong X, Mo Z, Bokoch G, Guo C, Li Z, Wu D. P-Rex1 is a primary Rac2 guanine nucleotide exchange factor in mouse neutrophils. Curr Biol. 2005; 15(20):1874-9. https://doi.org/10.1016/j.cub.2005.09.014.

71. Parks WC, Wilson CL, López-Boado YS. Matrix metalloproteinases as modulators of inflammation and innate immunity. Nat Rev Immunol. 2004; 4(8):617-29. https://doi.org/10.1038/nri1418.

72. Oddsdóttir C, Riley SC, Leask R, Edwards DR, Watson ED. Activities of matrix metalloproteinases- 9 and -2 in uterine fluid during induced equine endometritis. Pferdeheilkunde. 2008;24:70-3.

73. Soria-Valles C, Gutierrez-Fernandez A, Osorio FG, Carrero D, Ferrando AA,

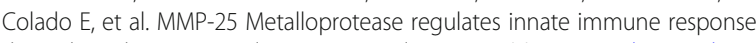
through NF-kappaB signaling. J Immunol. 2016;197(1):296-302. https://doi. org/10.4049/jimmunol.1600094.

74. Borroni EM, Bonecchi R, Buracchi C, Savino B, Mantovani A, Locati M. Chemokine decoy receptors: new players in reproductive immunology. Immunol Investig. 2008;37(5):483-97. https://doi.org/10.1080/088201308021 91318.

75. de la Torre YM, Locati M, Buracchi C, Dupor J, Cook DN, Bonecchi R, et al. Increased inflammation in mice deficient for the chemokine decoy receptor D6. Eur J Immunol. 2005;35(5):1342-6.

76. Martinez de la Torre Y, Buracchi C, Borroni EM, Dupor J, Bonecchi R, Nebuloni $M$, et al. Protection against inflammation- and autoantibodycaused fetal loss by the chemokine decoy receptor D6. PNAS. 2007;104(7): 2319-24. https://doi.org/10.1073/pnas.0607514104.

77. Zhou JH, Zhou QZ, Lyu XM, Zhu T, Chen ZJ, Chen MK, et al. The expression of cysteine-rich secretory protein 2 (CRISP2) and its specific regulator miR27b in the spermatozoa of patients with asthenozoospermia. Biol Reprod. 2015;92(1):28. https://doi.org/10.1095/biolreprod.114.124487.

78. Lim S, Kierzek M, O'Connor AE, Brenker C, Merriner DJ, Okuda H, et al. CRIS $P 2$ is a regulator of multiple aspects of sperm function and male fertility. Endocrinology. 2019;160(4):915-24. https://doi.org/10.1210/en.2018-01076.

79. Arangasamy A, Kasimanickam VR, DeJarnette JM, Kasimanickam RK. Association of CRISP2, CCT8, PEBP1 mRNA abundance in sperm and sire conception rate in Holstein bulls. Theriogenology. 2011;76(3):570-7. https:// doi.org/10.1016/j.theriogenology.2011.03.009.

80. Novak S, Smith TA, Paradis F, Burwash L, Dyck MK, Foxcroft GR, et al. Biomarkers of in vivo fertility in sperm and seminal plasma of fertile stallions. Theriogenology. 2010;74(6):956-67. https://doi.org/10.1016/j. theriogenology.2010.04.025.

81. Doty A, Buhi WC, Benson S, Scoggin KE, Pozor M, Macpherson M, et al. Equine CRISP3 modulates interaction between spermatozoa and polymorphonuclear neutrophils. Biol Reprod. 2011;85(1):157-64. https://doi. org/10.1095/biolreprod.110.084491.

82. Reddy T, Gibbs GM, Merriner DJ, Kerr JB, O'Bryan MK. Cysteine-rich secretory proteins are not exclusively expressed in the male reproductive tract. Dev Dyn. 2008:237(11):3313-23. https://doi.org/10.1002/dvdy.21738.

83. Evans J, D'Sylva R, Volpert M, Jamsai D, Merriner DJ, Nie G, et al. Endometrial CRISP3 is regulated throughout the mouse estrous and human menstrual cycle and facilitates adhesion and proliferation of endometrial epithelial cells. Biol Reprod. 2015;92(4):99. https://doi.org/1 0.1095/biolreprod.114.127480

84. Tugba Durlu-Kandilci N, Ruas M, Chuang KT, Brading A, Parrington J, Galione A. TPC2 proteins mediate nicotinic acid adenine dinucleotide phosphate (NAADP)- and agonist-evoked contractions of smooth muscle. J Biol Chem. 2010;285(32):24925-32. https://doi.org/10.1074/jbc. M110.129833.

85. Khananshvili D. The SLC8 gene family of sodium-calcium exchangers (NCX) - structure, function, and regulation in health and disease. Mol Asp Med. 2013;34(2-3):220-35. https://doi.org/10.1016/j.mam.2012.07.003.

86. Rebecchi MJ, Pentyala SN. Structure, function, and control of Phosphoinositide-specific phospholipase C. Physiol Rev. 2000;80(4):1291335. https://doi.org/10.1152/physrev.2000.80.4.1291.

87. Nadeau-Vallée M, Boudreault A, Leimert K, Hou X, Obari D, Madaan A, et al. Uterotonic Neuromedin $U$ receptor 2 and its ligands are Upregulated by 
inflammation in mice and humans, and elicit preterm birth. Biol Reprod. 2016:95(3):72. https://doi.org/10.1095/biolreprod.116.140905.

88. Berridge MJ. The inositol Trisphosphate/calcium signaling pathway in health and disease. Physiol Rev. 2016;96(4):1261-96. https://doi.org/10.1152/ physrev.00006.2016.

89. Katila T. Sperm-uterine interactions: a review. Anim Reprod Sci. 2001;68(3-4): 267-72. https://doi.org/10.1016/S0378-4320(01)00162-2.

90. Troedsson MHT, Liu IKM, Crabo BG. Sperm transport and survival in the mare: a review. Theriogenology. 1998;50(5):807-18. https://doi.org/10.1016/ s0093-691x(98)00185-x.

91. Xiao L, Pan G. An important intestinal transporter that regulates the enterohepatic circulation of bile acids and cholesterol homeostasis: the apical sodium-dependent bile acid transporter (SLC10A2/ASBT). Clin Res Hepatol Gastroenterol. 2017;41(5):509-15. https://doi.org/10.1016/j.clinre.201 7.02.001.

92. Sanchez R, Schuermann Y, Gagnon-Duval L, Baldassarre H, Murphy BD, Gevry N, et al. Differential abundance of IGF1, bile acids, and the genes involved in their signaling in the dominant follicle microenvironment of lactating cows and nulliparous heifers. Theriogenology. 2014;81(6):771-9. https://doi.org/10.1016/j.theriogenology.2014.01.005.

93. Jones RS, Parker MD, Morris ME. Monocarboxylate transporter 6-mediated interactions with prostaglandin F2alpha: in vitro and in vivo evidence utilizing a knockout mouse model. Pharmaceutics. 2020;12(3):201. https:// doi.org/10.3390/pharmaceutics12030201.

94. Murakami Y, Kohyama N, Kobayashi Y, Ohbayashi M, Ohtani H, Sawada Y, et al. Functional characterization of human monocarboxylate transporter 6 (SLC16A5). Drug Metab Dispos. 2005;33(12):1845-51. https://doi.org/10.1124/ dmd.105.005264.

95. Vadakedath S, Kandi V. Probable potential role of Urate transporter genes in the development of metabolic disorders. Cureus. 2018;10(3):e2382. https:// doi.org/10.7759/cureus.2382.

96. González RS, Rodriguez-Cruz M, Maldonado J, Saavedra FJ. Role of maternal tissue in the synthesis of polyunsaturated fatty acids in response to a lipiddeficient diet during pregnancy and lactation in rats. Gene. 2014;549(1):723. https://doi.org/10.1016/j.gene.2014.06.057.

97. Kemiläinen $\mathrm{H}$, Adam M, Mäki-Jouppila J, Damdimopoulou P, Damdimopoulos AE, Kere J, et al. The Hydroxysteroid (17beta) dehydrogenase family gene HSD17B12 is involved in the prostaglandin synthesis pathway, the ovarian function, and regulation of fertility. Endocrinology. 2016;157(10):3719-30. https://doi.org/10.1210/en.2016-1252.

98. Diel de Amorim M, Gartley CJ, Foster RA, Hill A, Scholtz EL, Hayes A, et al. Comparison of Clinical Signs, Endometrial Culture, Endometrial Cytology, Uterine Low-Volume Lavage, and Uterine Biopsy and Combinations in the Diagnosis of Equine Endometritis. J Equine Vet Sci. 2016;44:54-61. https:// doi.org/10.1016/j.jevs.2015.10.012.

99. Blankenberg D, Gordon A, Von Kuster G, Coraor N, Taylor J, Nekrutenko A, et al. Manipulation of FASTQ data with galaxy. Bioinformatics. 2010;26(14): 1783-5. https://doi.org/10.1093/bioinformatics/btq281.

100. Giardine B, Riemer C, Hardison RC, Burhans R, Elnitski L, Shah P, et al. Galaxy: a platform for interactive large-scale genome analysis. Genome Res. 2005; 15(10):1451-5. https://doi.org/10.1101/gr.4086505.

101. Kim D, Langmead B, Salzberg SL. HISAT: a fast spliced aligner with low memory requirements. Nat Methods. 2015;12(4):357-60. https://doi.org/10.1 038/nmeth.3317.

102. Chen YS, Lun ATL, Smyth GK. Differential expression analysis of complex RNA-seq experiments using edgeR. Front Probab Stat Sc. 2014:51-74.

103. Robinson MD, McCarthy DJ, Smyth GK. edgeR: a bioconductor package for differential expression analysis of digital gene expression data. Bioinformatics. 2010;26(1):139-40. https://doi.org/10.1093/ bioinformatics/btp616.

104. Bick JT, Zeng S, Robinson MD, Ulbrich SE, Bauersachs S. Mammalian Annotation Database for improved annotation and functional classification of Omics datasets from less well-annotated organisms. Database (Oxford). 2019;2019:baz086. https://doi.org/10.1093/database/ba z086.

105. Saeed Al, Sharov V, White J, Li J, Liang W, Bhagabati N, et al. TM4: a free, open-source system for microarray data management and analysis. Biotechniques. 2003;34(2):374-8. https://doi.org/10.2144/03342mt01.

106. Zhou Y, Zhou B, Pache L, Chang M, Khodabakhshi AH, Tanaseichuk O, et al. Metascape provides a biologist-oriented resource for the analysis of systems-level datasets. Nat Commun. 2019;10(1):1523. https://doi.org/10.103 8/s41467-019-09234-6.

107. Thorvaldsdóttir H, Robinson JT, Mesirov JP. Integrative genomics viewer (IGV): high-performance genomics data visualization and exploration. Brief Bioinform. 2013;14(2):178-92. https://doi.org/10.1093/bib/bbs017.

108. Ye J, Coulouris G, Zaretskaya I, et al. Primer-BLAST: a tool to design targetspecific primers for polymerase chain reaction. BMC Bioinformatics. 2012;13: 134. https://doi.org/10.1186/1471-2105-13-134.

109. Livak KJ, Schmittgen TD. Analysis of relative gene expression data using real-time quantitative PCR and the 2(-Delta Delta C(T)) method. Methods. 2001;25(4):402-8. https://doi.org/10.1006/meth.2001.1262.

\section{Publisher's Note}

Springer Nature remains neutral with regard to jurisdictional claims in published maps and institutional affiliations.
Ready to submit your research? Choose BMC and benefit from:

- fast, convenient online submission

- thorough peer review by experienced researchers in your field

- rapid publication on acceptance

- support for research data, including large and complex data types

- gold Open Access which fosters wider collaboration and increased citations

- maximum visibility for your research: over $100 \mathrm{M}$ website views per year

At BMC, research is always in progress.

Learn more biomedcentral.com/submissions 